\title{
Recursos minerais da Amazônia
}

\author{
BRENO AUGUSTO dOS SANTOS
}

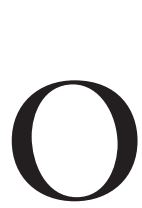

\section{Introdução}

S PROCEssos de ocupação da Amazônia têm apresentado, como característica marcante, o fato de serem orientados de fora para dentro, tendo como objetivo a resolução de problemas alheios à realidade regional, seja o abastecimento de mercados (normalmente externos), seja a absorção de contingentes migratórios expulsos de outras regiões em conseqüência das distorções do desenvolvimento socioeconômico brasileiro [Fig. 1].

Nas últimas três décadas, esses processos adquiriram proporções alarmantes, incrementados pela miséria que assola grande parte da população brasileira e estimulados pelos mais diversos interesses, que vêem na Amazônia a possibilidade de rápida capitalização a partir da posse da terra ou da exploração dos recursos naturais, particularmente madeira e ouro, a custo relativamente baixo.

Em decorrência, sua população cresceu mais de cinco vezes, atingindo cerca de 19 milhões de habitantes. Tudo isso aconteceu sem que houvesse um "Projeto para a Amazônia", que a partir do adequado zoneamento ecológico, através de estudos que identificassem as reais aptidões e limitações de cada área (e convenientemente monitorados), possibilitasse a orientação da ocupação humana com desenvolvimento sustentado. Houve políticas governamentais isoladas, algumas bem intencionadas, mas a maioria casuística e desastrada, que muitas vezes tiveram como resultado o caos ambiental e social.

Essa ocupação intempestiva e desorganizada não transcorreu impunemente, surgindo graves conflitos pela posse da terra e de suas riquezas, com prejuízos muitas vezes irrecuperáveis para as populações indígenas e o ecossistema. Legiões de deserdados passaram a ocupar seus territórios, convivendo com a fome, doenças (principalmente a malária), promiscuidade, vícios e violência.

O processo de ocupação da Amazônia tem acompanhado a tendência da economia brasileira, sendo essencialmente concentrador de renda. Alguns poucos têm feito fortuna com a exploração de suas riquezas, mas a maioria dos migrantes tem permanecido como marginalizados sociais.

Sua rede rodoviária, praticamente inexistente há trinta anos, hoje - embora mantida em condições precárias - é superior a 60 mil quilômetros. Tem sido o principal agente facilitador da ocupação do solo, com suas trágicas e irresponsáveis queimadas, que destruíram, no período, mais de 500 mil quilômetros quadrados da floresta tropical.

Os partidários do desenvolvimento a qualquer preço lembram que os acertos e desacertos da ocupação também ocorreram na expansão de fronteiras em 
outras regiões da Terra. Contudo, se esquecem do cenário e do momento histórico dos processos, com diferenças substanciais nos instrumentos que o homem tem a sua disposição. As trilhas foram substituídas por rodovias, o machado pela moto-serra, as canoas por aviões e helicópteros, o telégrafo pela comunicação via satélite, a informação pessoal por dados de sensores rastreadores espaciais, a interpretação individual pelo tratamento com softwares especializados, etc. Tudo isso faz com que as mudanças ocorram em grande velocidade, sem o tempo devido para a correta avaliação das conseqüências sobre um ecossistema essencialmente frágil.

\section{THE AMAZON REGION}

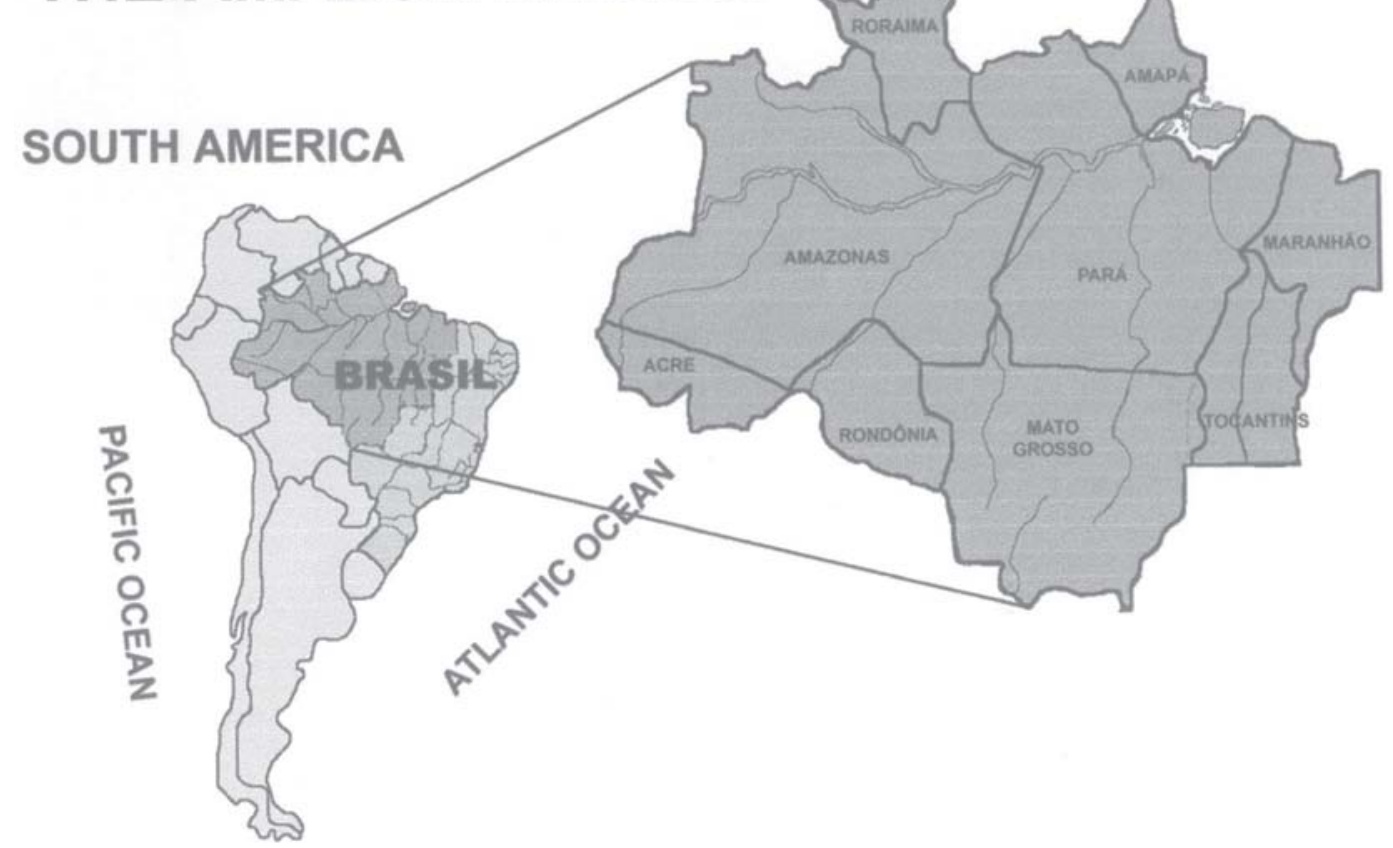

Figura l - Amazônia brasileira

Sem uma política adequada e coerente, o que poderia ser agente de um desenvolvimento harmônico e integrado transforma-se em arma de cobiça e destruição.

Assim, deve-se analisar a questão mineral na Amazônia como parte desse contexto, ou seja, a mineração é um dos agentes de ocupação, por ser a região parte de um país periférico da economia mundial, e uma das últimas fronteiras para a expansão da exploração mineral.

Essas premissas devem ser analisadas considerando-se as mudanças havidas nos cenários político e econômico do mundo, principalmente nos últimos 15 anos. 
Até o início da década de 1960, o conhecimento do subsolo da Amazônia estava restrito aos relatórios de viagem de poucos pesquisadores, normalmente limitados à calha dos grandes rios. A atividade mineral resumia-se apenas a um grande empreendimento - produção de minério de manganês pela ICOMI no Amapá - e a poucos garimpos de diamante, ouro ou cassiterita.

A partir dessa década, em decorrência de uma política governamental voltada para a integração da Amazônia, apoiada pelos incentivos fiscais, e da melhoria dos meios de comunicação e transporte, tem início a entrada de capitais destinados a sua ocupação, com conseqüente atração dos fluxos migratórios.

O mundo vivia o clima de pós-guerra, com exacerbação da guerra fria, num cenário em que os recursos minerais, além do valor comercial, ainda tinham um componente estratégico bastante valorizado. Por outro lado, dada a euforia daqueles anos dourados, sonhava-se com o crescimento ilimitado da economia mundial, com considerável expansão da industrialização e dos mercados nos países desenvolvidos e, conseqüentemente, do suprimento de matérias-primas. Surgem, então, previsões alarmistas sobre a breve escassez dos recursos minerais, ganhando corpo os primeiros movimentos conservacionistas.

Assim, os primeiros investimentos na Amazônia foram feitos por grandes corporações industriais multinacionais. Tinham como objetivo principal a verificação das potencialidades minerais dessa vasta região ainda desconhecida, considerando apenas o seu uso futuro. Estava presente a visão estratégica dos recursos minerais, pois buscava-se alternativas de suprimento para atender ao futuro crescimento do mercado ou prevenir a escassez decorrente de eventual crise nos países produtores, como decurso das políticas nacionalistas em vigor na época. Dessa forma é que os primeiros investimentos foram destinados à busca de minério de alumínio (cujo mercado estava em expansão) e de manganês (essencial para a indústria do aço), ambos dependentes da produção de poucos países.

Transformações profundas nesse cenário começaram a ocorrer a partir de 1973, como resultado do primeiro “choque do petróleo". De um lado, o início do período recessivo da economia mundial, que com maior ou menor intensidade tem atormentado a vida das populações, particularmente do mundo subdesenvolvido, reduz a taxa de crescimento do consumo dos bens minerais, com resultante queda dos preços. Este fato é agravado pelo aumento da oferta de muitos dos minérios, em decorrência do sucesso dos programas de prospecção e pesquisa, desenvolvidos na época por organizações governamentais e empresas, inclusive no Brasil - e particularmente na Amazônia (ferro, alumínio, manganês e estanho).

Por outro lado, o ouro - com o seu preço já desvinculado do dólar - acompanha a valorização do petróleo, passando o valor da onça troy de US\$31, em 1973, para US\$ 180 em 1974, e atingindo o valor máximo de US\$ 850 em 1980, após o segundo "choque do petróleo". Torna-se, assim, o principal objetivo de grande parte das empresas de mineração. 
Esses fatos - ampliação da oferta e redução da demanda - são acompanhados por outra mudança estrutural: transferência da mineração, e mesmo da industrialização primária dos minérios, para os países do terceiro mundo, em decorrência da exaustão de muitas fontes de produção, da racionalização no uso da energia e dos controles ambientais cada vez mais rígidos nos países ricos. Essa tendência é reforçada pela perda do valor estratégico dos bens minerais, que passaram a ser simples mercadorias com preços pressionados apenas pelas leis do mercado. Na década de 1980, o controle da tecnologia consolida-se na substituição do controle do suprimento dos insumos minerais, como instrumento estratégico para o desenvolvimento das nações.

As empresas multinacionais, que se afastaram da Amazônia durante a recessão da indústria mineral dos anos 1980, só há três anos reiniciaram seus projetos de prospecção. Isso ocorreu devido ao período de instabilidade política e econômica do fim da ditadura militar à transição para o governo democrático, bem como pelas restrições ao capital estrangeiro impostas na Constituição Brasileira de 1988, recentemente retiradas.

Entretanto, os programas atuais diferem bastante dos ocorridos décadas atrás. Não se busca mais o inventário das potencialidades minerais da região, mas cada empresa tem objetivos bem específicos, voltados para atender a lucratividade de seus investidores, sejam cotistas de fundos, sejam acionistas de grandes complexos industriais.

De um lado, empresas com produção industrial verticalizada, que buscam a descoberta de uma jazida que possibilite a continuidade de suprimento do insumo mineral, mas com características excepcionais, equivalente às melhores do mercado, e amplie a competitividade e a margem de lucro de seus produtos. Há interesse preferencial pelo cobre, zinco, níquel e caulim.

De outro, empresas, principalmente "júniores”, que buscam a descoberta de "Eldorados". A Amazônia possui muitos ambientes geológicos férteis para ouro e o declínio da corrida garimpeira dos anos 1970 e 1980 - mais de 800 mil garimpeiros estiveram em atividade, em decorrência de políticas governamentais equivocadas e com graves conseqüências ambientais - está liberando muitas áreas de produção. Esse tipo de investimento tem um componente especulativo, e as atividades dessas empresas estão sendo afetadas pela queda do preço do ouro e pela crise dos mercados asiáticos. Não se sabe até quando o ouro continuará sendo um bem valioso para o homem e objeto de febril busca. Como o seu maior uso é para a joalheria e, em parte, como ativo financeiro, acredita-se que seu valor mitológico persistirá enquanto o homem temer a volatilidade das moedas e acreditar na eternidade do amor, ou, de forma mais prática, os grandes produtores de ouro conseguirem manter preços que bem remunerem os seus custos. 


\section{A realidade do seu potencial mineral}

A Amazônia corresponde a uma das maiores regiões da Terra - ainda desconhecida - com potencialidade para a descoberta de bens minerais. Os primeiros empreendimentos, na década de 1960, tinham como diretriz básica a busca do desconhecido. Apesar das limitações ainda existentes ao conhecimento do seu subsolo, os programas de geologia das últimas décadas revelaram uma considerável variedade de ambientes geológicos, com potencialidade para depósitos minerais, desde os utilizados intensivamente pela indústria moderna até os mais valiosos.

Sabe-se que os minerais se acham distribuídos em todas as rochas da crosta terrestre, mas apenas são passíveis de exploração pelo homem quando encontrados em concentrações que permitam o seu aproveitamento econômico com a tecnologia disponível. As jazidas não ocorrem de forma aleatória, mas estão associadas a rochas ou a seqüências de rochas que, durante a sua formação ou evolução, apresentaram condições físico-químicas bastante favoráveis para a concentração e retenção do elemento de interesse econômico. A seleção dos ambientes geológicos com potencialidade mineral corresponde ao primeiro cuidado de qualquer programa de prospecção. Para se vislumbrar o significado do potencial da Amazônia, deve-se contemplar a avaliação de seus ambientes geológicos, antes de simplesmente repassar as estatísticas de sua produção mineral atual.

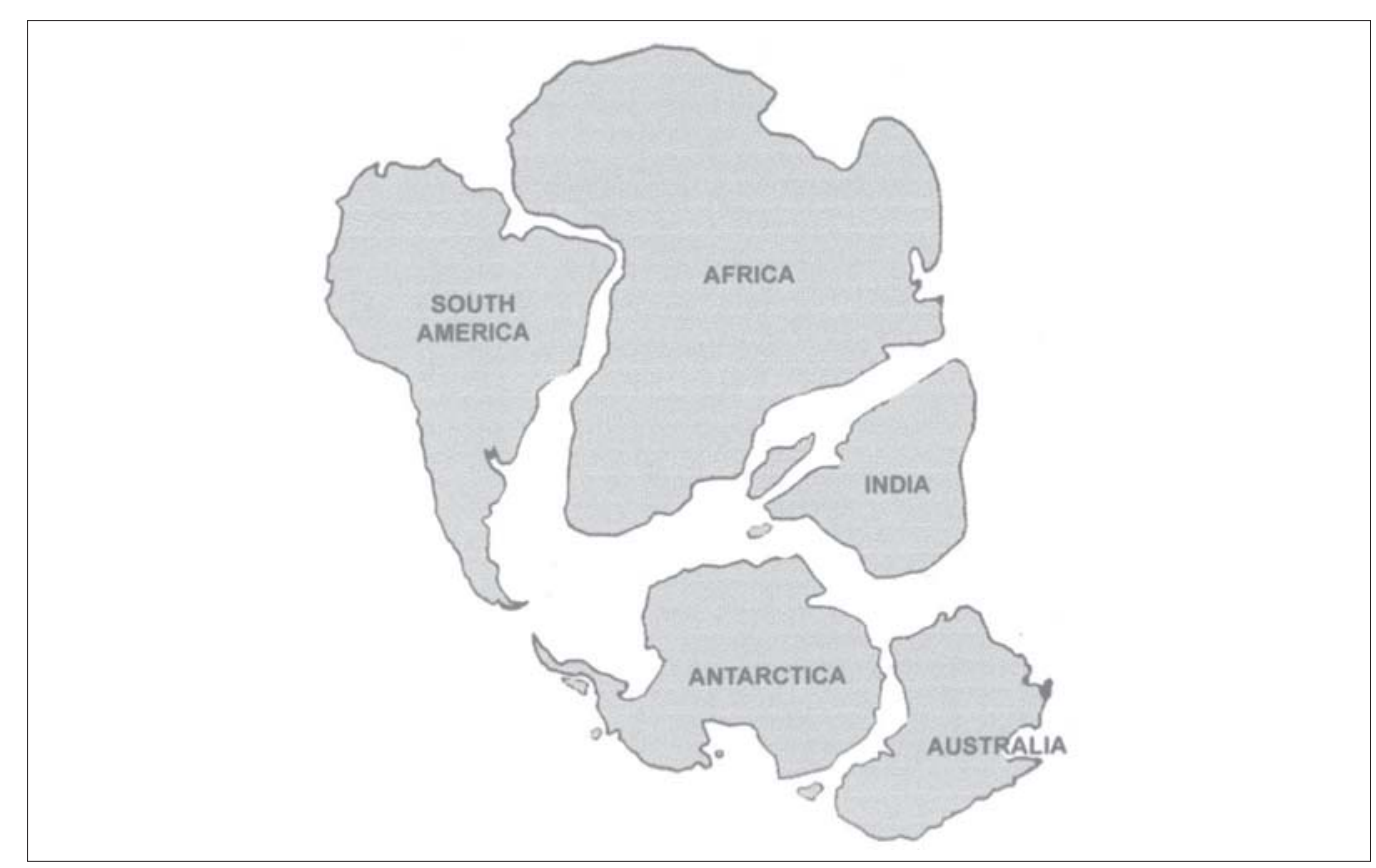

Figura 2 - Gondwana: 150 milhões de anos atrás

Ao analisarmos as áreas potenciais da Amazônia, temos que ter em conta que a configuração da Amazônia, como parte integrante do continente sul-americano, ocorreu em tempo geológico relativamente recente, a partir de $150 \mathrm{mi}-$ 
lhões de anos atrás. Grande parte de sua crosta foi consolidada quando a América do Sul ainda pertencia ao continente gondwânico, junto com a África, Antártida, Austrália e Índia [Fig. 2]. Por outro lado, a gênese de muitos de seus depósitos, como os de petróleo, gás, bauxita e caulim, está relacionada às mudanças estruturais e ambientais que ocorreram com a deriva do continente sul-americano, que também foram responsáveis pelo surgimento da cadeia andina e pela inversão das águas no vale amazônico.

Em termos mundiais, a maioria dos depósitos minerais metálicos está si tuada em terrenos pré-cambrianos, pertencentes ao mais longo período de formação da crosta terrestre, do início da solidificação do planeta até 570 milhões de anos atrás. As condições físico-químicas nesse período - particularmente na fase inicial do Arqueano, há mais de dois bilhões de anos - eram bastante diferentes das de hoje, com a crosta bem menos espessa, o que propiciava a ascensão de metais das zonas mais profundas da Terra.

$\mathrm{Na}$ Amazônia, as áreas de pré-cambriano correspondem a cerca de $40 \%$ do seu território [Fig. 3]. As suas seqüências vulcano-sedimentares (do tipo greenstone belt ou não), intrusões graníticas, derrames vulcânicos ácidos e intermediários, complexos alcalino-ultrabásicos e básico-ultrabásicos, e coberturas sendimentares apresentam potencialidade para uma grande variedade de depósitos minerais, tais como ferro, manganês, alumínio, cobre, zinco, níquel, cromo, titânio, fosfato, ouro, prata, platina, paládio, ródio, estanho, tungstênio, nióbio, tântalo, zircônio, terras-raras, urânio e diamante. Deve ser salientado que boa parte dos depósitos minerais, embora relacionados a rochas pré-cambrianas, foram formados através de processos de enriquecimento - laterização, erosão e concentração - em tempos mais recentes, do Terciário ao Quaternário.

As concentrações residuais de óxidos de manganês, descobertas na serra do Navio - atual estado do Amapá - na década de 1940, deram origem à primeira mineração da Amazônia. As minas, abertas em meados da década de 1950, encontram-se em fase final de explotação. Atualmente, os depósitos de minério de manganês com maior expressão econômica situam-se na região de Carajás. Ocorrências menores são conhecidas há várias décadas, na região do rio Sucunduri, no estado do Amazonas [Fig. 4].

Os primeiros depósitos de sulfetos de cobre da Amazônia foram descobertos na região de Carajás, na década de 1970. Recentemente, nas proximidades de Aripuanã, no extremo noroeste do estado de Mato Grosso, foram descobertas significativas ocorrências de sulfetos de zinco, com cobre e ouro subordinados [Fig. 4].

Os garimpos de ouro, que no século XIX desenvolveram-se apenas em duas áreas do Amazonas (Amapá e Gurupi), começaram a adquirir importância produtiva na década de 1960, com a descoberta dos aluviões do Distrito Aurífero do Tapajós, situado no sudoeste do estado do Pará. Entretanto, somente no 
início da década de 1980, com a descoberta de ouro na região de Carajás, é que se alastrou uma grande "corrida do ouro", que ultrapassou as fronteiras da Amazônia brasileira, envolvendo quase um milhão de garimpeiros. A explosão dessa atividade garimpeira foi motivada por vários fatores, destacando-se o agravamento da miséria de boa parte da população brasileira, principalmente a rural e nordestina, decorrente da falta de uma solução adequada para a questão agrária. A elevação do preço do ouro - ampliada no Brasil, até poucos anos atrás, pela diferença excessiva entre as cotações do dólar oficial e do mercado paralelo -, o atrativo despertado pela ampla divulgação na imprensa da descoberta de depósitos ricos como serra Pelada e a complacência - e mesmo um certo estímulo - das autoridades governamentais, durante a década passada, foram fatores que também contribuíram para a expansão da atividade garimpeira por toda a Amazônia.

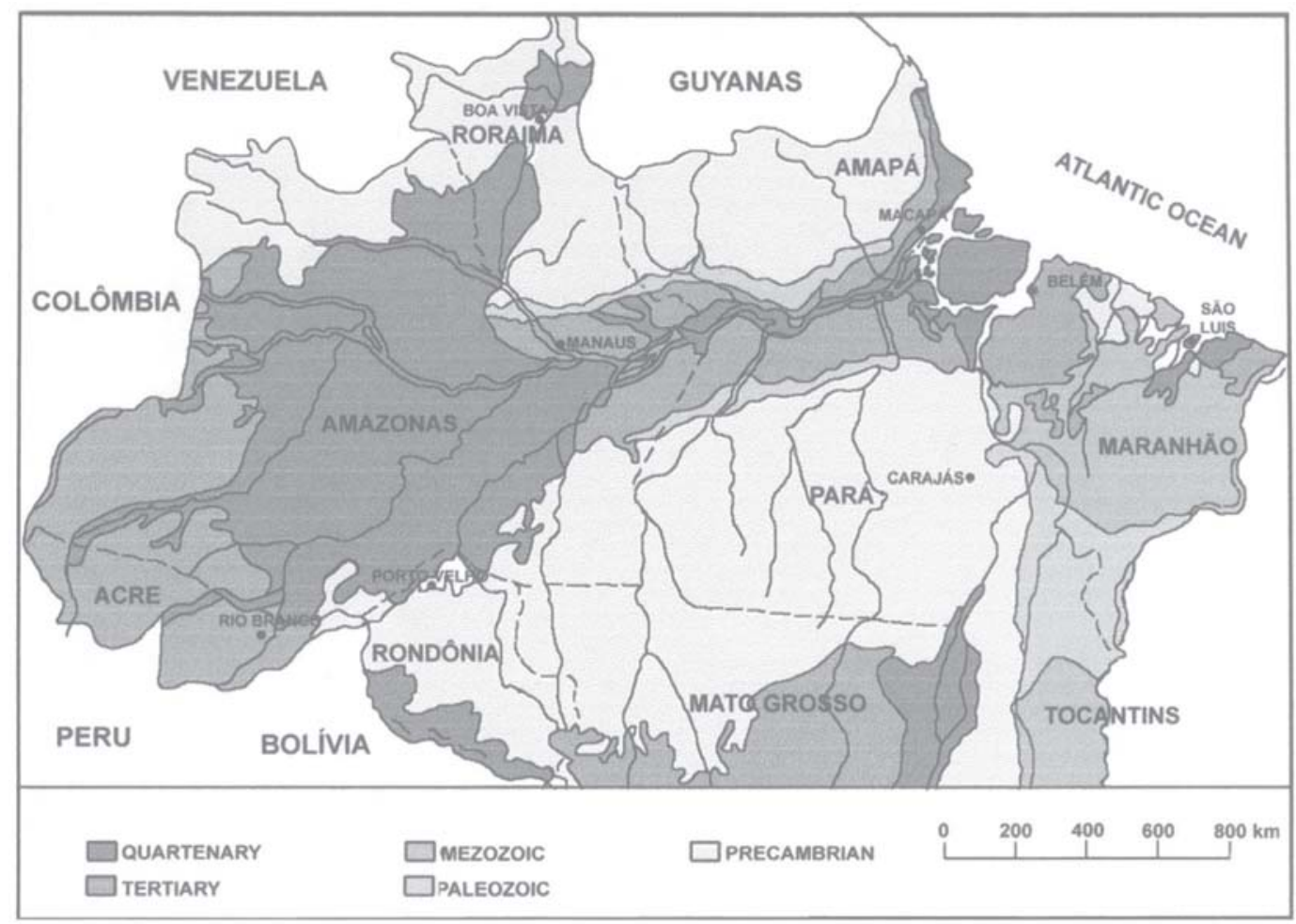

Figura 3 - Amazônia: mapa geológico simplificado

Entretanto, devido à exaustão dos depósitos superficiais mais ricos, acompanhada pela queda do preço do ouro e sensível redução da diferença cambial, esse modelo social e econômico de ocupação da Amazônia encontra-se em rápido declínio.

Muitos dos depósitos auríferos secundários - eluviões, aluviões ou leitos dos rios - estão relacionados com jazimentos primários passíveis do aproveitamento econômico. Parte dos empresários do garimpo, desde que com orientação e políticas adequadas, poderão transformar-se em pequenos ou médios mine- 
radores. Algumas tentativas governamentais nesse sentido foram implementadas na "Reserva Garimpeira do Tapajós", mas ainda sem resultados expressivos. Essa região foi responsável, nos últimos trinta anos, por uma produção da ordem de 400 toneladas, a maior de toda história do Brasil resultante de atividade artesanal. Houve mais de mil locais com atividade garimpeira, distribuídos numa área da ordem de 80 mil quilômetros quadrados. Apesar disso, os geólogos brasileiros estão divididos quanto à real potencialidade da região: uns acreditam que os indícios são muitos fortes para a existência de grandes depósitos; outros lembram que, como ocorreu na "corrida de ouro" do Alasca, uma infinidade de pequenos depósitos primários podem dar origem a concentrações residuais muito ricas.

Contudo, seja qual for o resultado empresarial da produção de ouro na Amazônia, os milhares de migrantes que foram atraídos pela "febre do ouro" da década passada estão engrossando as legiões dos "sem terra", que clamam por uma solução para a questão agrária, num país com dimensões continentais, mas onde as elites dominantes, desde o tempo das "capitanias hereditárias", têm na posse de grandes extensões territoriais uma das formas de seu poder político. $\mathrm{O}$ garimpo na Amazônia correspondeu a simples paliativo, apenas adiando por duas décadas - conforme já era previsível na época - a necessidade de uma solução para a questão agrária.

Além da reserva do Tapajós, a atividade garimpeira foi mais atuante ao sul de Carajás (Andorinhas, Tucumã e Cumarú), na região do rio Gurupi, no Amapá, no norte do estado de Mato Grosso (Juruena e Teles Pires), no alto rio Negro (Cabeça do Cachorro), em Rondônia (rio Madeira) e em Roraima (Surucucus e vizinhanças).

Ao sul de Carajás, o ouro está associado a seqüências de greenstone belts. Algumas ocorrências estão sendo pesquisadas por empresas, como as situadas nas proximidades da serra das Andorinhas. Também há pesquisa empresarial na região do Gurupi. Entretanto, apenas no antigo garimpo do Lourenço, no Amapá, houve atividade produtiva por empresa de mineração [Fig. 4].

Os ricos aluviões estaníferos de Rondônia foram responsáveis pela primeira “corrida garimpeira” da Amazônia, na década de 1960 - cerca de 10 mil garimpeiros estiveram envolvidos na produção de cassiterita, número bastante expressivo para a época. No final de década, a garimpagem foi proibida pelo governo federal, passando a produção para a mineração empresarial.

Na década de 1970, surgiram novos distritos estaníferos na Amazônia. Nas proximidades do rio Xingú, a oeste de Carajás, no estado do Pará, a descoberta foi feita por empresas de mineração, mas houve invasão garimpeira temporária. Posteriormente, a explotação foi completada por mineradoras. Na serra de Surucucus, no extremo oeste do estado de Roraima, na fronteira com a Venezuela, a descoberta foi conseqüência de levantamentos radarmétricos realizados pelo governo federal. A invasão garimpeira ocorrida em 1976 correspondeu ao primeiro contato de atividade produtiva capitalista com os índios ianománi. Por ser 
um contigente pequeno, da ordem de 800 pessoas, foi possível a rápida desativação do garimpo, sem grandes seqüelas para os ianománi - isso ocorreu com a "corrida do ouro" da década seguinte.

Somente no início dos anos 1980 é que foram descobertos os mais expressivos depósitos de cassiterita da Amazônia. A jazida do Pitinga, no estado do Amazonas, está em produção por uma empresa de mineração e a de Bom Futuro, no estado de Rondônia, continua com atividade garimpeira, apesar dos esforços governamentais para regularizar uma atividade empresarial [Fig. 4].

A sensível queda do preço do estanho no mercado internacional tem desestimulado a abertura de minas, bem como a busca de novos depósitos.

Os corpos graníticos da Amazônia também são potenciais para depósitos de zircônio, nióbio, tântalo, tungstênio e terras-raras. Na mina do Pitinga há mineralizações associadas de columbita-tantalita, zirconita e criolita. No sudeste do estado do Pará há pequenos depósitos de volframita, que foram explorados parcialmente através da garimpagem

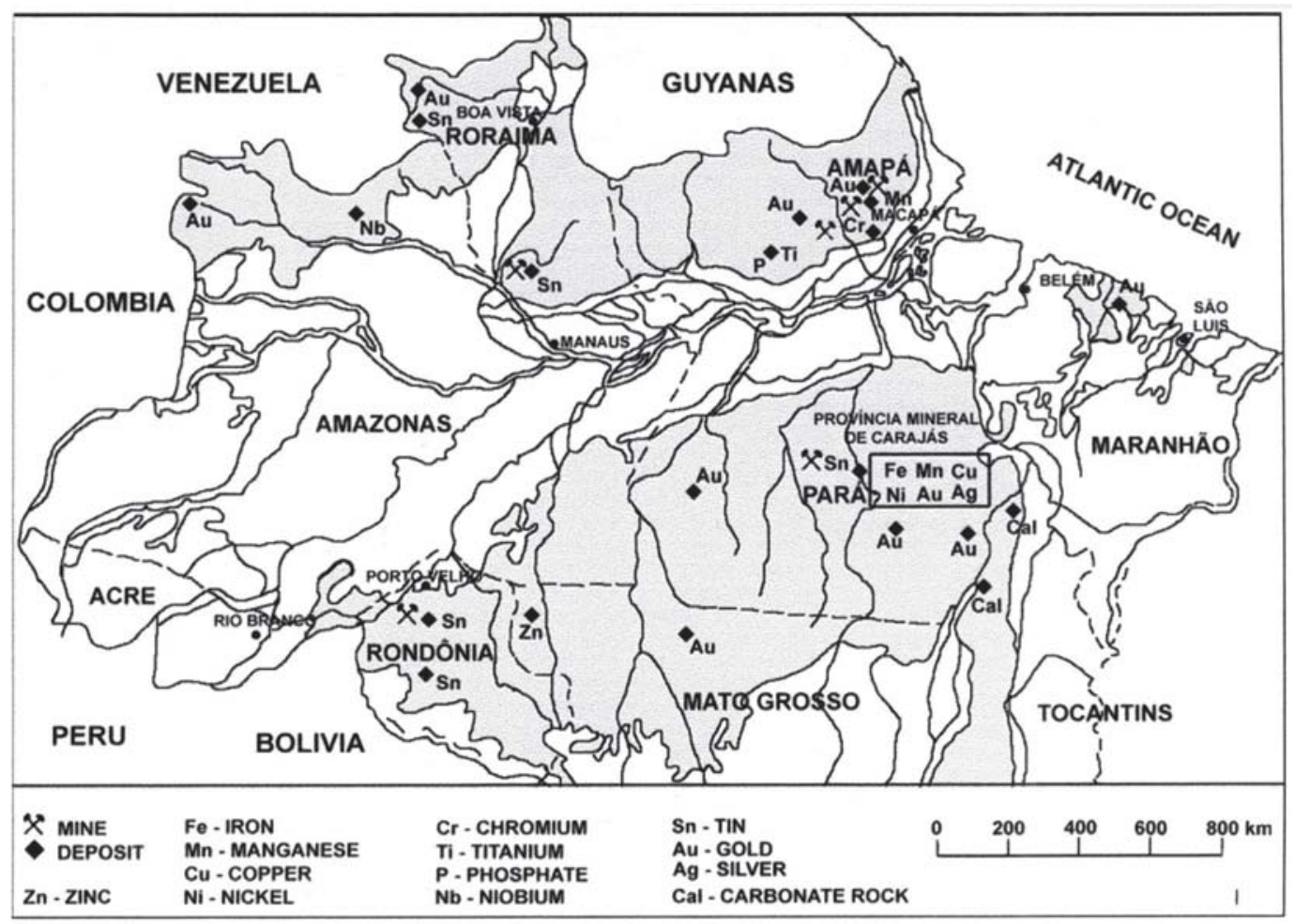

Figura 4 - Pré-cambriano na Amazônia: principais depósitos minerais

Na Amazônia são conhecidos três complexos alcalino-ultrabásicos potenciais para depósitos de titânio, fosfato, nióbio e terras-raras: Seis Lagos, no estado do Amazonas, e Maicuru e Maraconaí, no estado do Pará. Em Seis Lagos há um grande potencial em nióbio. O complexo de Maicuru está associado a um 
corpo de cabornatito; além de suas reservas de fosfato, há um considerável potencial em titânio, mas sob a forma de anatásio, mineral para o qual ainda não há tecnologia que permita o seu aproveitamento industrial em bases econômicas [Fig. 4].

Há vários complexos básico-ultrabásicos potenciais para depósitos de níquel, cromo, platina e platinóides. No estado do Amapá, nas proximidades do rio Vila Nova, foi implantada pequena mina de cromita, destinada à produção de ferro-liga [Fig. 4].

Os processos de laterização em rochas pré-cambrianas podem levar à formação de depósitos de bauxita: há ocorrências associadas a rochas graníticas e a rochas básicas. Todavia, não foram objeto de maior interesse econômico, em função das jazidas de minério de alumínio de excelente qualidade - derivadas de rochas cretáceas ou terciárias - situadas nas proximidades do rio Amazonas.

No passado, houve garimpos de diamante no rio Tocantins, nas proximidades da cidade de Marabá. Hoje, a pequena produção de diamante está restrita à atividade garimpeira no norte de Roraima, na fronteira com a Venezuela, e à pequena mineração no estado de Mato Grosso. Há notícias de ocorrências de mineralizações primárias de diamante, associadas a kimberlitos, sem haver, contudo, produção [Fig. 4].

Muitos dos corpos graníticos da Amazônia apresentam características físicas que permitem o seu aproveitamento como rocha ornamental ou de revestimento. As áreas mais próximas dos meios de transporte poderão vir a ser lavradas para competir no promissor mercado internacional.

Depósitos de calcário de idade pré-cambriana são conhecidos no norte do estado do Tocantins e no sudeste do Pará, nas proximidades do rio Araguaia. Apresentam composição calcítica ou dolomítica, havendo possibilidade de sua utilização como insumo destinado à fabricação de cimento ou à indústria metalúrgica, bem como para corretivo de solos.

Grandes movimentos tectônicos, precursores do início da deriva do continente sul-americano, deram origem a duas importantes bacias paleozóicas: do Amazonas, na parte central, e do Parnaíba (do Maranhão), que tem apenas sua borda ocidental situada na região. As duas bacias estão parcialmente recobertas por sedimentos mesozóicos e cenozóicos.

Embora as seqüências paleozóicas (570 - 230 M.A.) sejam potenciais para depósitos de carvão, a evolução das duas bacias não possibilitou a formação de jazimentos expressivos de carbono fóssil. Em relação a depósitos de petróleo e, principalmente, gás natural, ainda há boa possibilidade de novas descobertas.

Programas realizados pela Petrobrás, nas últimas duas décadas, levaram à localização de depósitos de óleo e gás. As descobertas mais significativas ocorreram na região dos rios Juruá (gás) e Urucu (gás e óleo), na sub-bacia do alto Amazonas [Fig. 5]. 


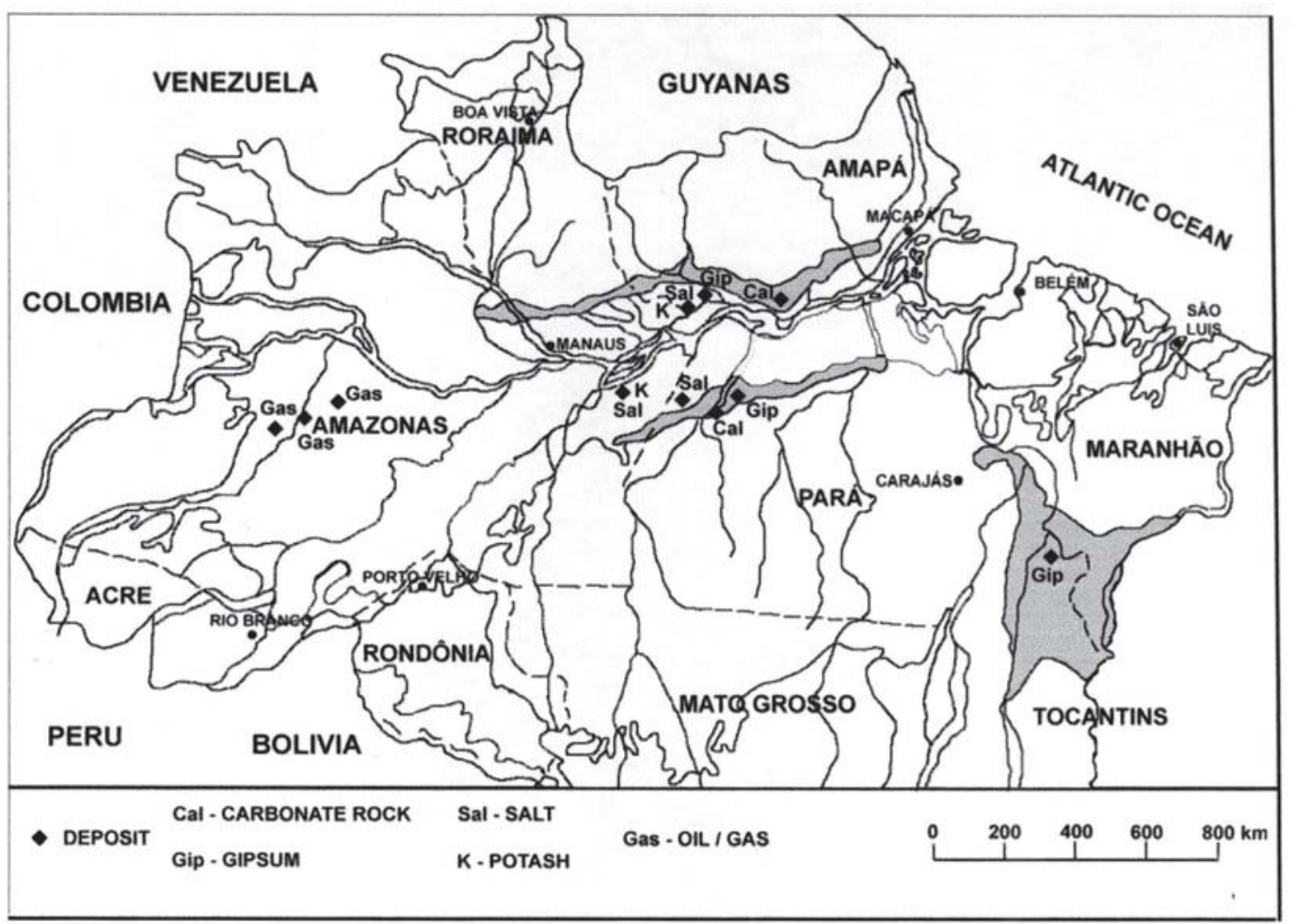

Figura 5 - Paleozóico na Amazônia: principais depósitos minerais

Entretanto, alguns especialistas em prospecção de petróleo acreditam que as possibilidades da região, principalmente para gás, são bem maiores que as detectadas até o presente. Esta conclusão é baseada na existência de condições para a geração e acumulação comercial de hidrocarbonetos. Chegam a ampliar a possibilidade de sucesso inclusive para as sub-bacias do médio e baixo Amazonas.

Do Paleozóico, há na Amazônia consideráveis depósitos de calcário, associados a seqüências do Carbonífero. Esses depósitos têm sido pesquisados para a fabricação de cimento; porém, poderão vir a ter importância como corretivo de solos, quando houver um programa de desenvolvimento sustentado que possibilite o aproveitamento seletivo dos solos da Amazônia, particularmente junto à calha do grande rio [Fig. 5].

Os sedimentos químico-evaporíticos do Carbonífero superior apresentam horizontes de salgema, sais de potássio, anidrita e gipsita. Os depósitos de evaporitos estão recobertos por sedimentos mais recentes e foram localizados através de sondagens da Petrobrás na sub-bacia do médio Amazonas, em profundidades que variam de 400 a 1.000 metros. Foram interceptados tanto na borda sul - região de Nova Olinda - Maués e Tapajós - como na borda norte da bacia - região do Nhamundá e Trombetas. Nas proximidades de Nova Olinda, em Fazendinha, a Petrobrás pesquisou expressivos depósitos de sais de potássio, associados a salgema [Fig. 5]. 
Na bacia do Parnaíba, há leitos de calcário e gipsita associados às seqüências clasto-químicas permianas [Fig. 5].

O Mesozóico (230 - 65 M.A.), na bacia do Amazonas, foi marcado por prolongada erosão até o início dos tempos cretáceos. Assim, os registros desse período estão restritos às manifestações vulcânicas básicas, preservadas sob a forma de sills e diques de diabásio.

Na bacia do Parnaíba, as coberturas mesozóicas estão bem distribuídas, merecendo destaque a sedimentação cretácea.

Uma deposição sedimentar com características continentais, predominantemente flúvio-lacustre, cobriu extensas áreas das bacias do Amazonas e Parnaíba, bem como das bacias costeiras. Como essa sedimentação teve início no Cretáceo, a perfeita caracterização dessa cobertura ainda não é uma questão resolvida, persistindo dúvidas quanto à estratigrafia e à nomenclatura, particularmente nas sub-bacias do médio e do baixo Amazonas, e na plataforma Bragantina - no leste do estado do Pará.

Na sub-bacia do alto Amazonas, essa sedimentação apresenta horizontes extensos de linhito, mas geralmente de pequena espessura e baixa qualidade, $\mathrm{o}$ que impede o seu aproveitamento econômico [Fig. 6].

$\mathrm{Na}$ plataforma Bragantina, ocorrem leitos de calcário que permitem sua utilização para a fabricação de cimento [Fig. 6].

A evolução do relevo e os processos de laterização que atuaram sobre essa cobertura areno-argilosa terciária - ou cretácea - deram origem a extensos depósitos de bauxita, que estão concentrados em três distritos principais: Trombetas (médio Amazonas), Almeirim (baixo Amazonas) e Paragominas-Tiracambú (plataforma Bragantina). Esses distritos são responsáveis pelo terceiro maior potencial em bauxita do mundo, superados apenas pelos da Austrália e da Guiné. A mineração foi implantada apenas na jazida do Trombetas [Fig. 6].

O minério de alumínio da Amazônia motivou a construção da hidrelétrica de Tucuruí, a fim de atender aos complexos de produção de alumina-alumínio da Alunorte e Albrás, nas proximidades de Belém, e da Alumar, em São Luís [Fig. $8]$.

Parte dos depósitos de bauxita, dos distritos de Almeirim e ParagominasTiracambú, apresentam características químicas - baixo teor de ferro - que permitem sua utilização na indústria de refratários. Foram abertas duas pequenas minas para o aproveitamento deste tipo de minério, nas proximidades das cidades de Almeirim e de Paragominas [Fig. 6].

A cobertura terciária - ou cretácea - da Amazônia também tem importância econômica pelos seus expressivos depósitos de caulim, distribuídos em três distritos principais: Manaus (médio Amazonas), Almeirim (baixo Amazonas) e 
Capim (plataforma Bragantina) [Fig. 6]. O caulim da região apresenta excepcionais qualidades para revestimento de papel (tipo coating). Três minas estão em atividade: uma no estado do Amapá, nas proximidades do rio Jari, e duas no distrito do Capim. Há previsões de que, em breve, a Amazônia, em particular a região do Capim, venha a se transformar no principal centro mundial de produção de caulim do tipo coating.

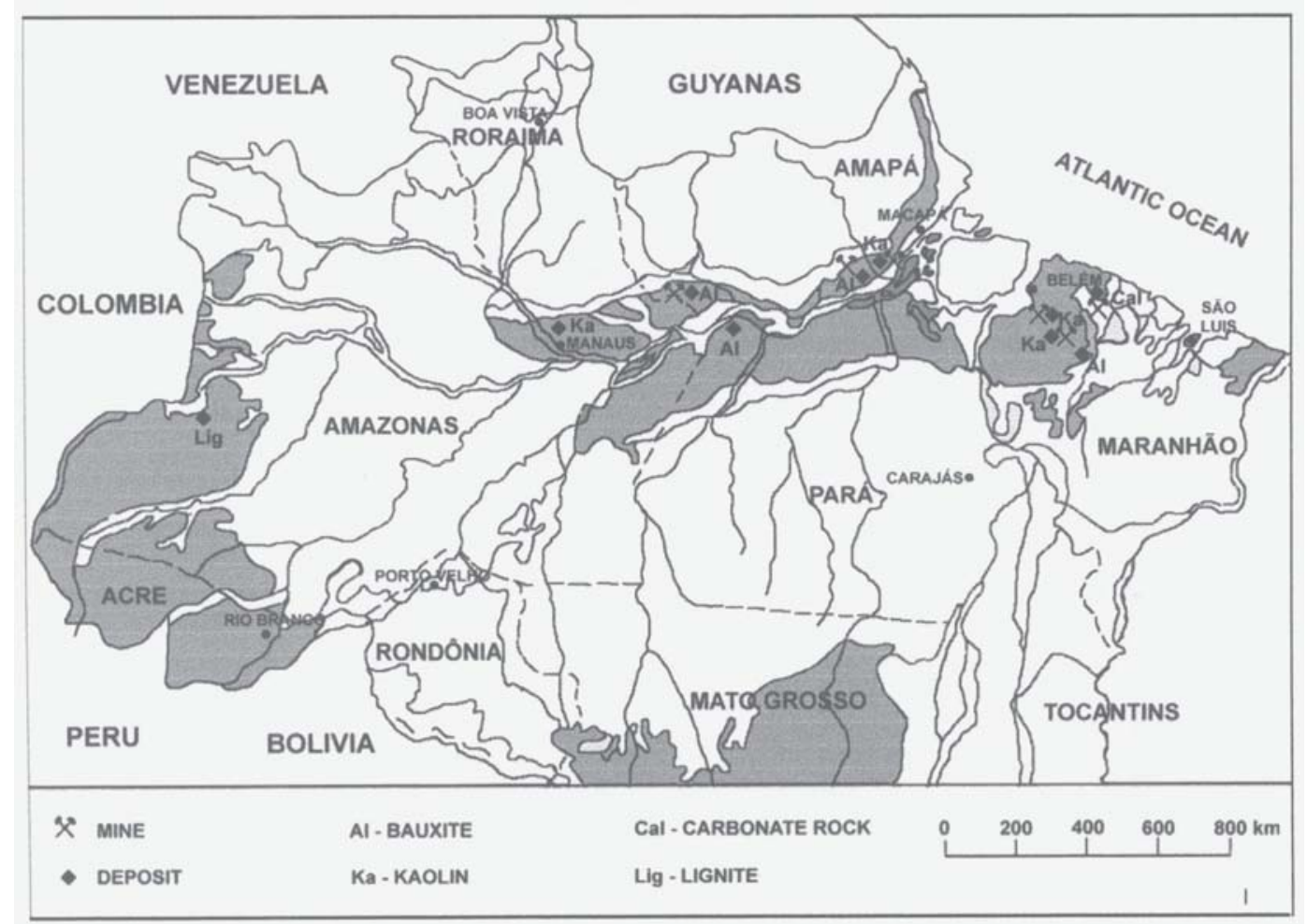

Figura 6 - Terciário na Amazônia: principais depósitos minerais

Na Amazônia, particularmente na sub-bacia do alto Amazonas, localizamse as mais representativas áreas com sedimentos quaternários do país. Contudo, a importância econômica do Quaternário está restrita aos aluviões mineralizados, principalmente a ouro e cassiterita, que se distribuem pelas mais diversas áreas da região, em terrenos pré-cambrianos, e que motivaram a explosão garimpeira das últimas décadas.

\section{Província mineral de Carajás}

Entre as áreas pré-cambrianas da Amazônia, destaca-se a "província mineral de Carajás". Sua evolução foi beneficiada por uma série de eventos geológicos, desde a consolidação de sua crosta até os tempos mais recentes, todos bastante favoráveis à formação de depósitos minerais. A conjunção de fatores, tais 
como tectonismo, vulcanismo, plutonismo, intemperismo e erosão, ocorrida numa área relativamente limitada - da ordem de 40 mil quilômetros quadrados - deu origem a um conjunto expressivo de jazimentos minerais de interesse econômico.

$\mathrm{Na}$ província mineral de Carajás, predominou um vulcanismo básico arqueano, responsável pela metalogenia do ferro, do cobre (com zinco subordinado), do manganês e do ouro. O plutonismo granítico contribuiu para remobilizar - talvez adicionando conteúdo metálico ao sistema - e concentrar os elementos minerais. $\mathrm{O}$ magmatismo ultramáfico introduziu níquel na província - sendo que, localmente, na sua extremidade leste, existe a presença de cromo, platina e platinóides. A atuação conjugada do intemperismo e da erosão, em tempos mais recentes, sobre sedimentos clasto-químicos relacionados com o vulcanismo básico arqueano foi responsável pela concentração de depósitos residuais de ferro e manganês, bem com de ouro sobre rochas básicas e de níquel laterítico associado aos corpos ultramáficos [Fig. 7].

A geologia de Carajás possui características próprias, não reproduzidas em outras províncias metalogenéticas da Terra. Alguns geocientistas que têm estudado a região chegam a considerar o vulcanismo básico arqueano como sendo um greenstone belt, mas com características específicas nessa província - greenstone belt do tipo Carajás.

Tudo começou na segunda metade da década de 1960, quando duas empresas americanas iniciaram programas de prospecção mineral na região com o objetivo de descobrir jazidas de manganês: a Union Carbide, para suprir suas fábricas de pilhas eletrolíticas, e a United States Steel, para alimentar suas siderúrgicas. Ambas tiveram sucesso em seus objetivos: a Union Carbide localizou os depósitos do Sereno, em 1966, nas proximidades de Marabá, mas a United States Steel, um ano depois, foi mais aquinhoada pela sorte, descobrindo os depósitos de Buritirama e também as fabulosas jazidas de ferro de Carajás.

As jazidas de ferro de Carajás, com seus 18 bilhões de toneladas de minério, correspondem à maior concentração de alto teor já localizada no planeta. Estão distribuídas em quatro setores principais: serra Norte (N1, N4 e N5), serra Sul (S11), serra Leste e serra de São Félix, no extremo oeste da região [Figs. 7 e 8].

A Companhia Vale do Rio Doce (CVRD), estatal federal recentemente privatizada - iniciou sua explotação em 1985, no braço leste da jazida N4. Recentemente, a lavra também foi estendida para o braço oeste da N4 e para a jazida N5, ampliando a capacidade de produção anual para cerca de 50 milhões de toneladas. A quase totalidade do minério é destinada ao mercado externo (Japão, Alemanha, Itália e outros). Na área de influência da ferrovia de Carajás a São Luís - 890 quilômetros - há algumas usinas destinadas à produção de ferrogusa [Fig. 8].

Além dos dois depósitos de manganês localizados nas primeiras pesquisas em Carajás, há também o do igarapé Azul, descoberto no início dos anos 1970. A mineração foi implantada apenas nessa jazida, com produções anuais ao redor 
de um milhão de toneladas. As características do minério permitem a seleção de produtos para utilização siderúrgica, eletrolítica e química [Figs. 7 e 8].

O primeiro depósito econômico de cobre da Amazônia foi descoberto em Carajás, em meados da década de 1970, nas proximidade do igarapé Salobo e a noroeste das jazidas de ferro de serra Norte. O cobre está associado a magnetita e ouro, com prata subordinada. Já foi concluído o projeto para implantação da mineração, que está na dependência apenas de reavaliação econômica e financeira.

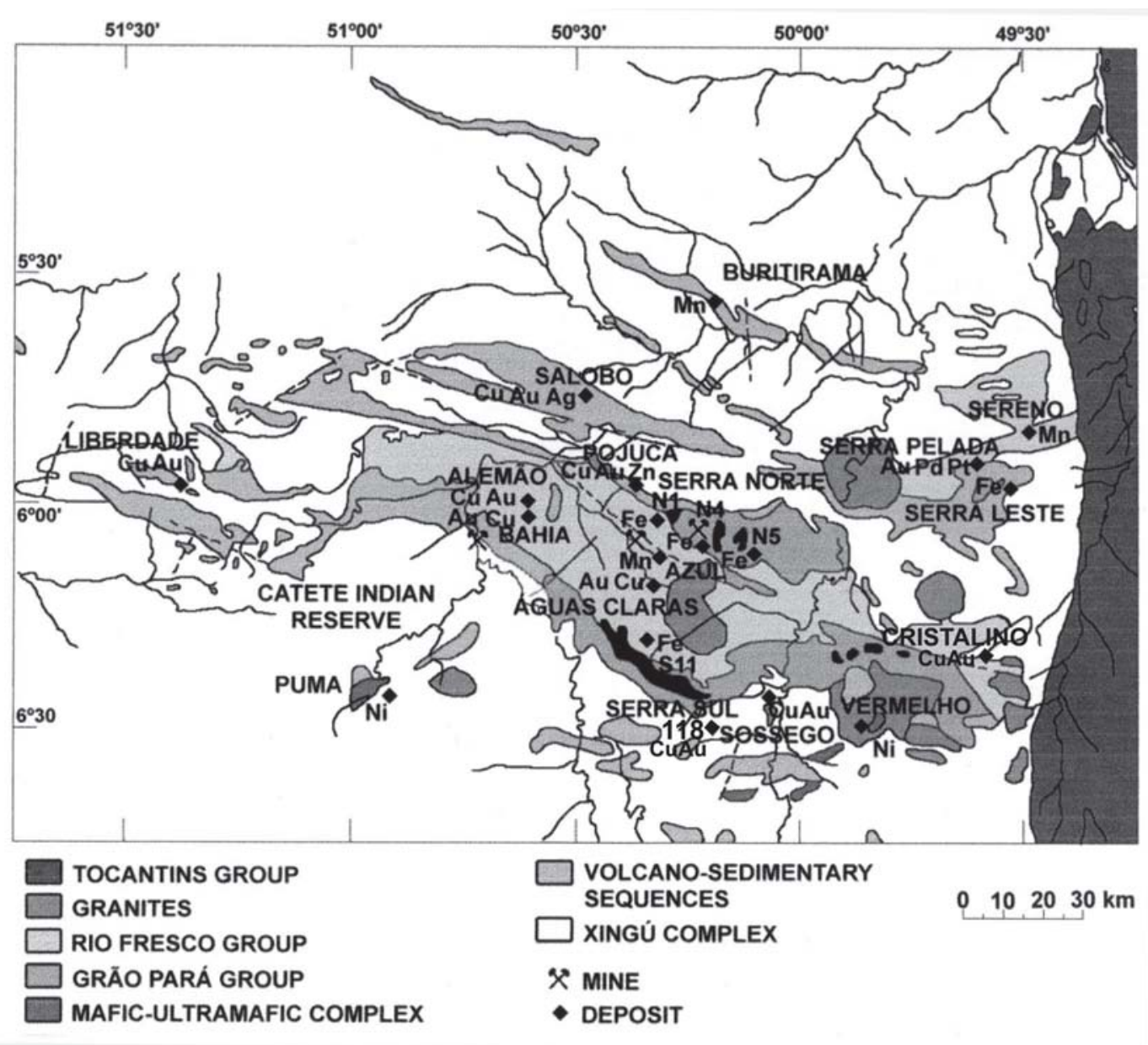

Figura 7 - Província Mineral de Carajás:

mapa geológico simplificado e principais depósitos minerais

Depósitos menores de cobre, localmente com zinco associado, foram descobertos na mesma época, no prolongamento oeste da serra Norte, nas proximidades do igarapé Pojuca.

Nas cabeceiras do igarapé Bahia - onde, na década de 1970, foram identificados os primeiros indícios de cobre em Carajás (anomalias geoquímicas em sedimentos de corrente) - descobriu-se recentemente expressivos depósitos de cobre (Corpo Alemão), associados a magnetita e ouro, que estão sendo avaliados. 


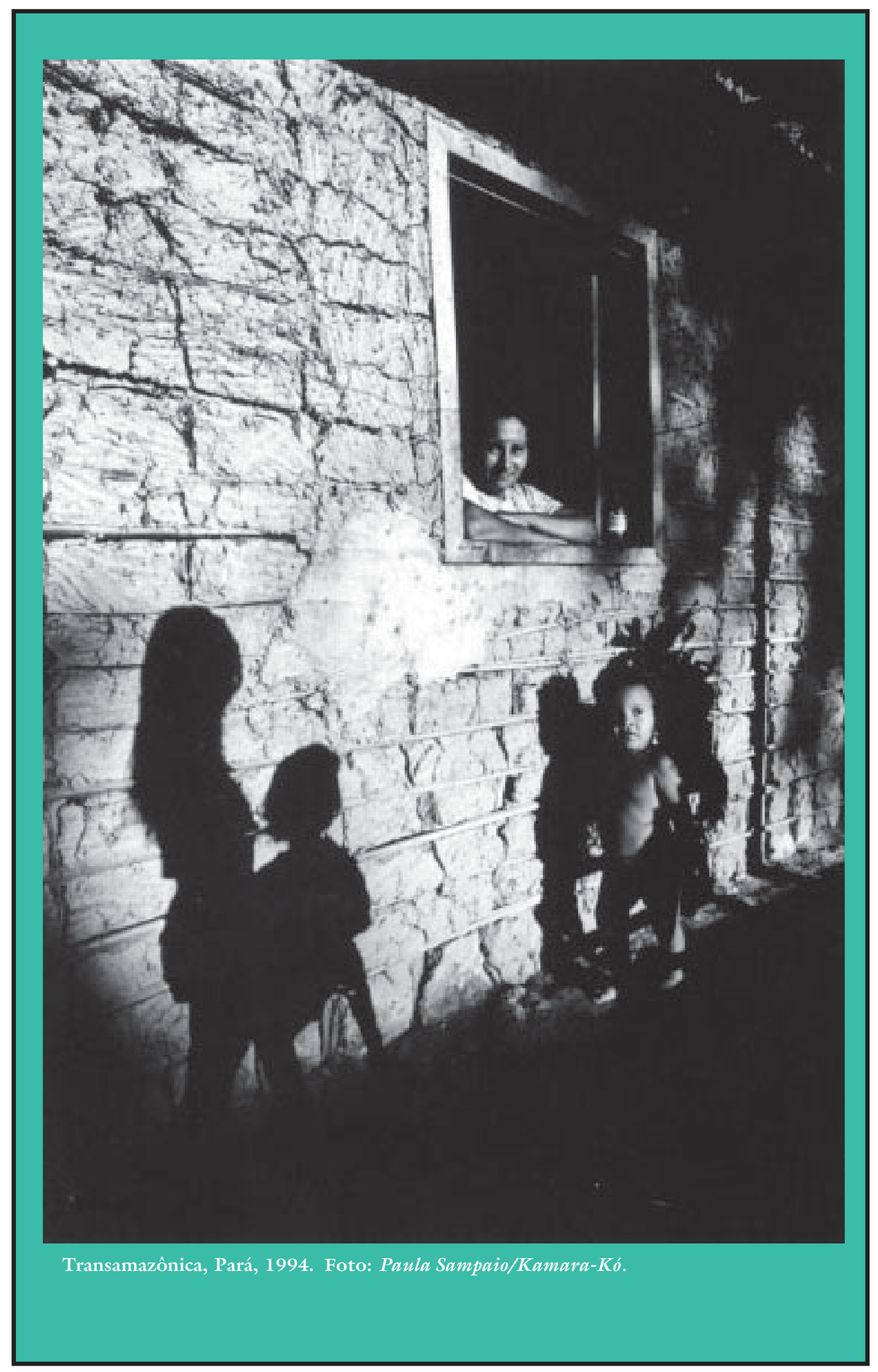




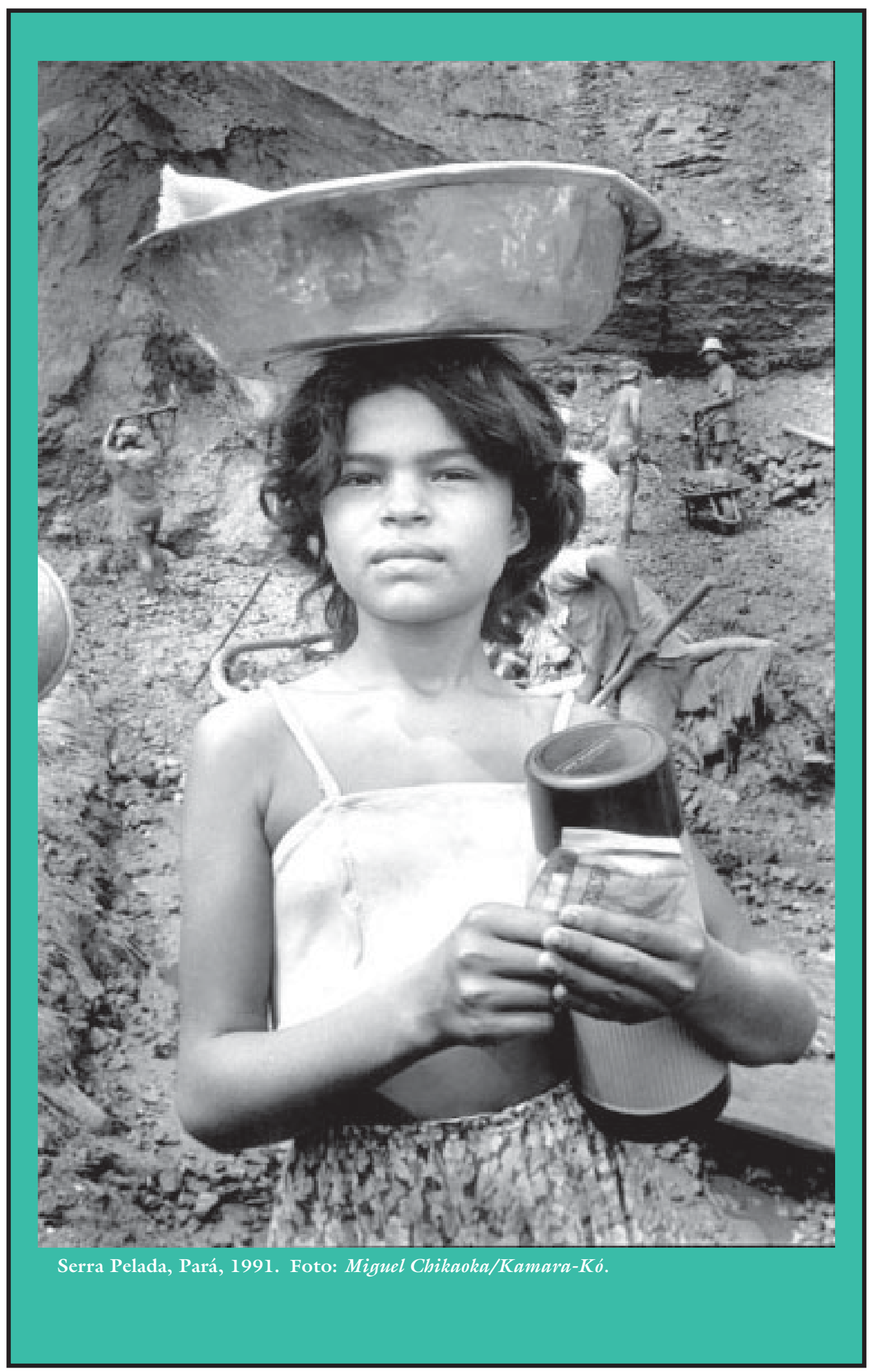

Estudos AvanÇAdos 16 (45), 2002 
Como esses corpos não afloram na superfície, sua descoberta foi fruto da integração de dados aerogeofísicos e geoquímicos, efetuada com a utilização de softwares especializados pela equipe da DOCEGEO - empresa de exploração geológica da CVRD.

Esses estudos permitiram a seleção de mais de cem alvos com potencialidade para ocorrências de cobre, alguns com programas de pesquisa em desenvolvimento (Gameleira, Sossego, Liberdade, etc.). Os depósitos têm como característica fundamental a associação com magnetita e ouro. Alguns apresentam semelhanças com o tipo pórfiro [Figs. 7 e 8].

Após a privatização da CVRD, a partir de alvos pré-selecionados pelos levantamentos aerogeofísicos, dois novos depósitos foram selecionados e estão em fase final de avaliação: Cristalino e 118.

A CVRD readquiriu o controle total da jazida do Sossego (durante a fase de pesquisa, $50 \%$ estava sob o controle da Phelps Dodge) e está iniciando a implantação da lavra. Será a primeira mina de cobre de Carajás.

Pesquisadores, bem como técnicos das empresas que atuam em Carajás, afirmam que a província de Carajás apresenta um considerável potencial, podendo vir a ser um importante pólo de produção de cobre no início do século XXI, só superado pelos Andes chilenos.

Entretanto, ainda não há uma política governamental que oriente o seu aproveitamento econômico com o justo desenvolvimento regional.

A pesquisa da anomalia de cobre do igarapé Bahia possibilitou a descoberta, em 1985, de um depósito residual de ouro, resultante da atuação dos processos de laterização em rochas vulcânicas básicas mineralizadas a cobre e ouro. Corresponde à mais importante jazida de ouro pesquisada até o presente na Amazônia. Sua lavra foi iniciada em 1991; sua capacidade atual de produção é de 10 toneladas por ano, o que a classifica como a maior mina de ouro do Brasil. Os recursos totais em ouro, na zona intemperizada, eram da ordem de 100 toneladas.

No leste da província, entre as jazidas de manganês do Sereno e de ferro de serra Leste, situa-se expressivo depósito de ouro - onde, no início da década de 1980, surgiu uma das mais espetaculares áreas de produção artesanal do mundo contemporâneo. O garimpo de serra Pelada chegou a ter 60 mil homens em atividade, numa cava que atingiu 200 metros de diâmetro e 80 metros de profundidade. Durante seis anos, foram produzidas cerca de 50 toneladas de ouro. Entretanto, mais do que a quantidade, o que impressiona nesse depósito é a concentração do ouro: durante o garimpo, foram retirados blocos com até 60 quilos. Associado ao ouro, há platina, paládio e ródio. Com o encerramento da produção garimpeira, foram reiniciadas as pesquisas geológicas para se verificar a possibilidade de implantação da mineração [Figs. 7 e 8].

Deverá haver expressiva produção de ouro, como subproduto da mineração dos depósitos de cobre de Carajás. Na lavra da jazida do Salobo, está prevista a recuperação de 8 toneladas de ouro, para uma produção anual de 200 mil toneladas de cobre. 


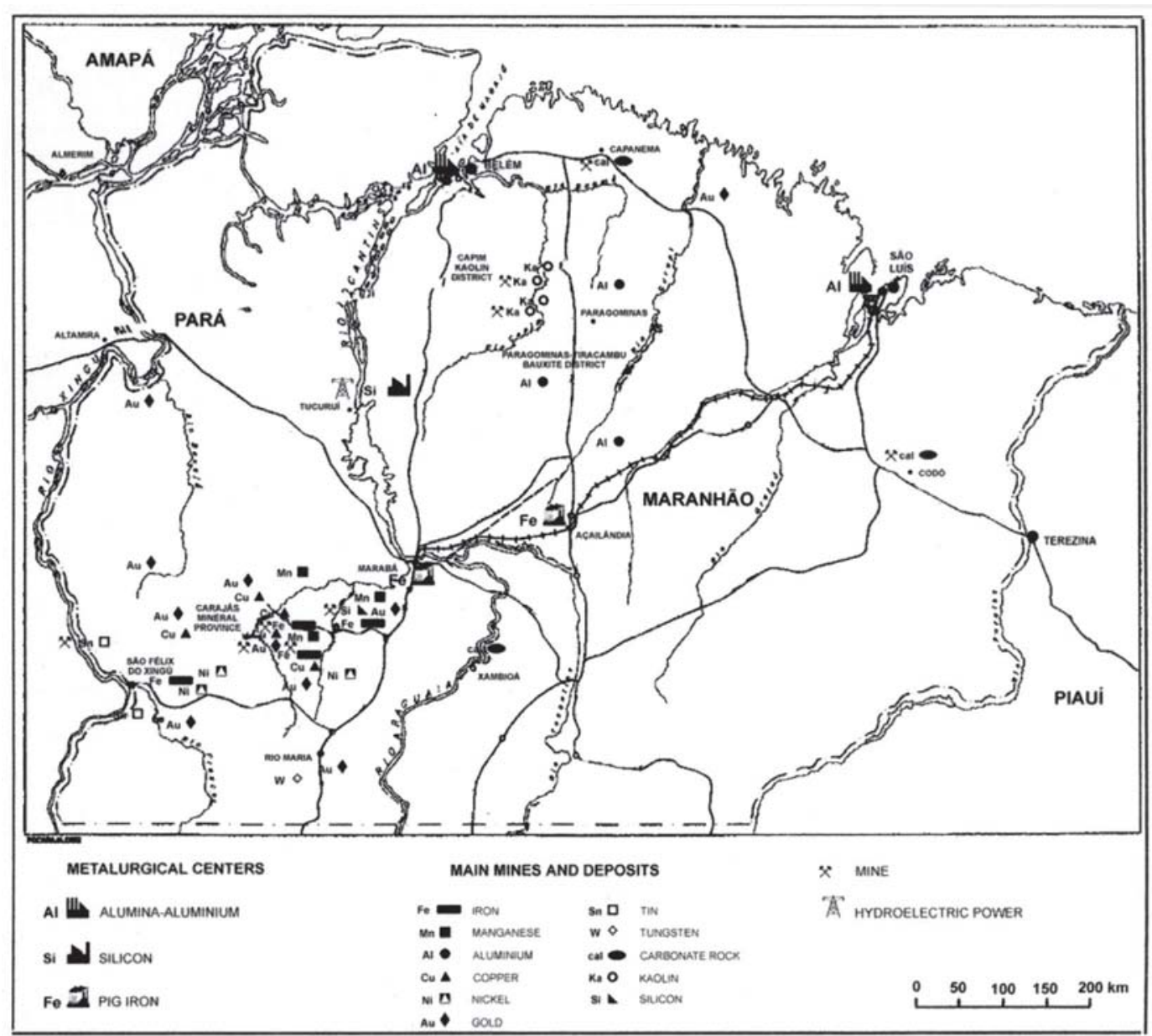

Figura 8 - Projeto Grande Carajás:

principais depósitos minerais e desenvolvimento mínero-metalúrgico

Os processos de laterização, que atuaram nos corpos ultramáficos de Carajás, deram origem a três depósitos limoníticos e garnieríticos de níquel: Vermelho, Onça e Puma. Entretanto, os recursos avaliados ainda não permitiram a sua explotação em bases econômicas [Figs. 7 e 8].

Além dos elementos citados, a região apresenta potencialidade para depósitos de zinco, estanho e, eventualmente, diamante. Entretanto, sua evolução metalogenética determinou uma vocação preferencial para ferro e cobre, com ouro subordinado.

Deve ser lembrado que o programa de exploração geológica em Carajás encontra-se na sua terceira onda. Na primeira, no final da década de 1960 e início dos anos 1970, foram localizados os depósitos minerais com fortes indícios superficiais: ferro, manganês e níquel. Com a entrada da DOCEGEO, em 1974, a utilização de técnicas mais aprimoradas de geoquímica e geofísica possibilitou um novo ciclo de descobertas: cobre-ouro do Salobo e Pojuca, e ouro do Igarapé 
Bahia e Andorinhas. A partir de década de 1990, a introdução de tecnologia de ponta em geofísica e a utilização de softwares especializados para a integração rápida, e com inúmeras simulações, dos dados de geologia, geoquímica e geofísica, permitiram a elaboração de um novo modelo metalogenético para a província. A primeira conclusão desse processo foi a identificação do seu alto potencial para cobre e ouro, associado a óxidos de ferro, muitas vezes magnéticos - a descoberta do expressivo depósito de cobre e ouro do Corpo Alemão, junto à mina de ouro do igarapé Bahia, foi a primeira comprovação dessa hipótese.

A província mineral de Carajás é considerada uma das mais importantes anomalias metalogenéticas da crosta terrestre, comparável, em potencial mineral e econômico, às regiões do Abitibi Belt, no Canadá, e de Witerwatersrand, na África do Sul. Tem a seu favor a imaturidade do nosso conhecimento geológico, pouco mais de 30 anos, enquanto que as demais províncias apresentam mais de um século de história. Mesmo assim, sua produção de minério de ferro, manganês e ouro corresponde a um valor bruto da ordem de US\$ 1 bilhão por ano.

\section{Considerações finais}

O conhecimento da geologia da Amazônia, de modo geral, ainda é bastante preliminar - no mesmo nível em que os países com mineração desenvolvida encontravam-se no início do século XX. Tornam-se necessários maiores investimentos em estudos básicos, bem como para o desenvolvimento de uma tecnologia de prospecção e pesquisa adaptada à realidade regional, para que se possa ter um melhor conhecimento de seus recursos minerais.

Mesmo assim, os trabalhos executados nas três últimas décadas já obtiveram expressivos testemunhos da riqueza de seu subsolo. A fertilidade de alguns de seus ambientes geológicos - onde jazidas de classe mundial já foram dimensionadas - indicam que a Amazônia deverá ocupar posição de destaque na produção de alguns bens minerais, tais como minério de ferro, alumínio, cobre, ouro, manganês, caulim, estanho e, eventualmente, gás.

A mineração empresarial caracteriza-se pelo uso intensivo de capital e tecnologia, mas com baixa utilização de mão-de-obra, normalmente especializada. Entretanto, essa atividade tem contribuído para o crescimento regional, através da infra-estrutura implantada, dos empregos indiretos gerados e dos impostos pagos. Indiretamente, tem agravado o problema social da região, por criar pólos de atração e facilidades para a penetração das correntes migratórias.

Por outro lado, o garimpo utiliza mão-de-obra intensiva, geralmente despreparada, e tecnologia primitiva. A atividade garimpeira ocupou um grande contingente de trabalhadores, porém de imigrantes, transferindo a miséria do Nordeste para a Amazônia.

O aproveitamento da riqueza mineral tem sido responsabilizado pelos problemas ambientais e sociais impostos à região nos últimos anos. Na realidade, a Amazônia passou a fazer parte das opções dos marginalizados pelo processo 
socioeconômico brasileiro, que tentam encontrar caminhos de sobrevivência no garimpo, na posse da terra ou na periferia dos grandes projetos e das cidades.

Como a atividade garimpeira encontra-se em declínio, seus trabalhadores estão engrossando as legiões dos "sem terra". Torna-se necessário criar opções econômicas que permitam a participação dessa população - como, por exemplo, o desenvolvimento agrícola sustentado das terras férteis e o reflorestamento das zonas degradadas da região. Os simples assentamento dessa população em lotes, sem qualquer orientação técnica e científica, vai contribuir para agravar os problemas ambientais e sociais.

A discussão da problemática ambiental, relacionada com a extração mineral na Amazônia, tem sido exacerbada em função dos conflitos decorrentes da atividade garimpeira. De fato, merecem cuidado e preocupação os danos causados por centenas de milhares de homens, que no período de duas décadas vasculharam boa parte das drenagens da região.

Considerando que o garimpo normalmente atua em depósitos minerais superficiais, a área desmatada é bastante significativa - mas muito inferior à das queimadas motivadas pela posse da terra. Na exploração do cascalho mineralizado, feita normalmente com uso de jatos de água, há remoção de uma quantidade maior de material argiloso, que é lançado nos pequenos e grandes rios, tornando-os barrentos.

Entretanto, o problema ambiental que tem causado maior polêmica está relacionado com o uso do mercúrio na concentração do ouro. Além da situação do próprio garimpeiro envolvido na amalgamação do ouro, foi levantada a possibilidade de ter havido contaminação dos peixes nas regiões com maior atividade garimpeira, como na bacia do Tapajós. Felizmente, estudos recentes sugerem que a metilização do mercúrio, e sua entrada na cadeia biológica, ocorreu apenas em casos isolados, e uma maior conscientização dos garimpeiros tem reduzido a contaminação profissional.

A expansão garimpeira também contribuiu de maneira direta para a disseminação da malária na região, tanto em função do aumento da população nas áreas de risco, agravado pelas condições sanitárias do garimpo, como pela constante migração de seus habitantes.

O caos da atividade garimpeira impede a apuração das responsabilidades pelo danos ambientais do passado, mas torna necessário um maior controle e fiscalização pelas autoridades governamentais no presente.

Quanto à mineração empresarial, os principais projetos implantados na Amazônia têm apresentado controle ambientais bastante satisfatórios. Nas minas de Carajás - ferro, manganês e ouro - o desmatamento tem ficado restrito às áreas de mineração e acesso, tendo havido reflorestamento, com espécies locais, das zonas não mais utilizadas. A construção de barragens de rejeito impedem que os resíduos sólidos da mineração sejam lançados na drenagem regional. 
A Companhia Vale do Rio Doce, enquanto era estatal e com a participação de institutos de pesquisa e universidades, patrocinou estudos da flora, da fauna, dos sítios arqueológicos, bem como desenvolveu programas de apoio às comunidades indígenas nas áreas sob influência do projeto Carajás. Com a empresa privatizada, espera-se que os novos donos continuem seguindo a mesma política.

Tudo isso não impediu que a área do projeto corresponda a uma verdadeira "ilha" de preservação ambiental, rodeada por um cinturão de ocupação, motivada pelos mais diversos objetivos - posse da terra, pecuária, extração da madeira e garimpagem.

Superados os equívocos iniciais, as demais áreas de mineração da Amazônia - manganês de serra do Navio, caulim do Jari e do Capim, bauxita do Trombetas e cassiterita do Pitinga - também apresentam cuidados ambientais satisfatórios.

Algumas áreas da Amazônia apresentam vocação natural para uma industrialização baseada nos insumos minerais. No caso específico de Carajás - onde, ao lado da riqueza mineral da própria província, somam-se os distritos da bauxita de Paragominas-Tiracambú e de caulim do Capim - deverão ser contemplados os projetos relacionados com a siderurgia, metalurgia do alumínio, silício, cobre e níquel, e refino do ouro, bem como a fabricação de papel [Fig. 8].

É necessário que se encontrem novas soluções para a questão energética da região. As grandes hidrelétricas têm apresentado altos custos financeiros e ambientais, que comprometem todo o processo de desenvolvimento. Alternativas poderiam ser encontradas na utilização sustentada da biomassa e do gás natural. O crescimento industrial da Amazônia vai depender de disponibilidade energética competitiva, mas de fontes ecologicamente corretas, para que seus produtos não sofram rejeição nos mercados cada vez mais seletivos e críticos.

Os recursos minerais da Amazônia somente poderão dar maior contribuição ao desenvolvimento nacional - e regional - quando o processo de industrialização do país permitir a elaboração de produtos finais com elevado grau de tecnologia agregada. Só assim será possível uma melhor remuneração para os produtos de origem mineral, que tenham maior competitividade nos mutantes mercados atuais, num mundo onde há enorme diferença entre exportar potato chips ou micro chips.

Investimentos terão que ser feitos para o desenvolvimento de uma competência científica e tecnológica na Amazônia, voltada para a sua realidade e seus recursos. E, antes de tudo, é necessário que sejam feitos esforços para a valorização do homem da região, para que ele possa participar - com responsabilidade e usufruir - com qualidade de vida - do aproveitamento de suas riquezas.

A Amazônia precisa ser melhor conhecida em toda sua complexidade física e biológica para que a utilização de seus recursos realmente possa significar evolução econômica e social da população do Brasil, e da própria humanidade. 
Talvez a avidez por lucros a curto prazo e a qualquer preço desses tempos de globalização econômica insensível venha a contribuir para acelerar o saque de seu patrimônio mineral e biológico - e essas preocupações venham a ser lembradas apenas como um sonho utópico de alguns cientistas.

Bibliografia recomendada

AB' SABER, Aziz Nacib. A Amazônia: do dicurso à práxis. (São Paulo: Editora da Universidade de São Paulo, 1996), 320 p. [Ilustrado.]

ALMEIDA, F. F. M. de. "A Evolução dos Cratons Amazônico e do São Francisco Comparada com a de seus Homólogos do Hemisfério Norte" em Congresso Brasileiro de Geologia, 30, vol. 6, pp. 2293-407 (Recife: Sociedade Brasileira de Geologia, 1978).

. "Origem e Evolução da Plataforma Brasileira". B. Div. Geol. Mineral. DNPM, $\mathrm{n}^{\circ} 241$ (Rio de Janeiro: 1967), 36p.

ALMEIDA JR., José Maria Gonçalves de (org.) Carajás: desafio politico, ecologia e desenvolvimento (São Paulo: Brasiliense; Brasília: CNPQ, 1986), 633 p. [Ilustrado.]

ALVIM, Paulo de T. "Agricultura Apropriada para Uso Contínuo dos Solos na Região Amazônica”, Esp. Amb. Planej., vol. 2, no 11, (Rio de Janeiro: março 1990).

ASSAD, Roberto. "Depósitos de Bauxita na Amazônia” em Congresso Brasileiro de Geologia, 30, vol. 6, pp. 2511-16 (Recife: Sociedade Brasileira de Geologia, 1978).

BAHYA, Raymundo Ruy Pereyra. “O Petróleo e o Gás Natural na Amazônia”, palestra proferida no Comando da $8^{a}$ Região Militar de Belém em 1980.

BAILLY, Paul A. "Mineral Exploration Philosophy", Min. Cong. J., vol. 58, no 4, p. 31 (Washington: 8 de abril de 1972).

. "The Role of Luck in Mineral Exploration", Min. Cong. J., vol. 65, n 4, pp. 56-61 (Washington: abril 1979).

BARBOSA, Octávio. "Geologia Básica e Econômica da Área do Médio Tapajós, Estado do Pará”, B. Div. Fom. Prod. Mineral DNPM, no 126 (Rio de Janeiro: 1966).

; Andrade Ramos, José Raimundo de; Gomes, Franklin de Andrade et alii. Geologia estratigráfica, estrutural e econômica da área do Projeto Araguaia (Rio de Janeiro: IBGE, 1966). 94p. [Brasil. Departamento Nacional da Produção Mineral. Monografia, 19.]

BECKER, Berth e MACHADO, Lia. "Uma Nova Fronteira para o Século XXI", Ci. Hoje, vol. 1, no 3, pp. 45-6 (Rio de Janeiro: novembro/dezembro 1982).

BEISIEGEL, V. de R. (comp.) "Distrito Ferrífero da Serra dos Carajás" em Simpósio de Geologia da Amazônia, Anexo dos Anais, pp. 21-46 (Belém: Sociedade Brasileira de Geologia, 1982).

e Farias, N. F. "Ocorrências de Cobre na Serra dos Carajás" em Congresso Brasileiro De Geologia, 30, vol. 4, pp. 1419-30 (Recife: Sociedade Brasileira de Geologia, 1978)..

BERNARDELLI, A. L. "Depósito de Níquel Laterítico do Vermelho" em Simpósio de Geologia da Amazônia, Anexo dos Anais, pp. 87-95 (Belém: Sociedade Brasileira de Geologia, 1982). 
BERNARDELLI, A. L. "Jazida de Manganês do Azul” em Simpósio de Geologia da Amazônia, Anexo dos Anais, pp. 47-59 (Belém: Sociedade Brasileira de Geologia, 1982).

PROJETO RADAMBRASIL. Folha NA. 19 Pico da Neblina: geologia, geomorfologia, pedologia, vegetação e uso potencial da terra (Rio de Janeiro: Departamento Nacional da Produção Mineral, 1976), 380 p. [Levantamento de Recursos Naturais, 11.]

Folha NA. 20 Boa Vista e parte das Folhas NA .21 Tumucumaque, NB. 20

Roraima e NB. 21: geologia, geomorfologia, pedologia, vegetação e uso potencial da terra (Rio de Janeiro: Departamento Nacional da Produção Mineral, 1975), 428 p. [Levantamento de Recursos Naturais, 8.]

Folba NA. 21 Tumucumaque eparte da Folba NB. 21:geologia, geomorfologia, pedologia, vegetação e uso potencial da terra (Rio de Janeiro: Departamento Nacional da Produção Mineral, 1975), 370 p. [Levantamento de Recursos Naturais, 9.]

Folba NA / NB. 22 Macapá: geologia, geomorfologia, solos, vegetação e uso potencial da terra (Rio de Janeiro: Departamento Nacional da Produção Mineral, 1974). [Levantamento de Recursos Naturais, 6.]

Folba SA. 19 Içá: geologia, geomorfologia, pedologia, vegetação e uso potencial da terra (Rio de Janeiro: Departamento Nacional da Produção Mineral, 1977), 452 p. [Levantamento de Recursos Naturais, 14.]

Folha SA. 20 Manaus: geologia, geomorfologia, pedologia, vegetação e uso potencial da terra (Rio de Janeiro: Departamento Nacional da Produção Mineral, 1978), 628 p. [Levantamento de Recursos Naturais, 18.]

Folha SA. 21 Santarém: geologia, geomorfologia, pedologia, vegetação e uso potencial da terra (Rio de Janeiro: Departamento Nacional da Produção Mineral, 1976), 522 p. [Levantamento de Recursos Naturais, 10.]

Folha SA. 22 Belém: geologia, geomorfologia, solos, vegetação e uso potencial da terra (Rio de Janeiro: Departamento Nacional da Produção Mineral, 1974). [Levantamento de Recursos Naturais, 5.]

Folba SA. 23 São Luis e parte da folba SA. 24 Fortaleza: geologia, geomorfologia, solos, vegetação e uso potencial da terra (Rio de Janeiro: Departamento Nacional da Produção Mineral, 1973). [Levantamento de Recursos Naturais, 3.]

Folha SB. 19 Juruá : geologia, geomorfologia, pedologia, vegetação e uso potencial da terra (Rio de Janeiro: Departamento Nacional da Produção Mineral, 1977), 436 p. [Levantamento de Recursos Naturais, 15.]

Folha SB. 20 Purus: geologia, geomorfologia, pedologia, vegetação e uso potencial da terra (Rio de Janeiro: Departamento Nacional da Produção Mineral, 1978), 566 p. [Levantamento de Recursos Naturais, 17.]

Folha SB. 21 Tapajós: geologia, geomorfologia, solos, vegetação e uso potencial da terra (Rio de Janeiro: Departamento Nacional da Produção Mineral, 1975). [Levantamento de Recursos Naturais, 7.]

Folha SB. 22 Araguaia e parte da folha SC. 22 Tocantins: geologia, geomorfologia, solos, vegetação e uso potencial da terra (Rio de Janeiro: Departamento Nacional da Produção Mineral, 1974). [Levantamento de Recursos Naturais, 4.]

Folha SB. 23 Teresina e parte da folha SB. 24 Jaguaribe: geologia, 
geomorfologia, solos, vegetação e uso potencial da terra (Rio de Janeiro: Departamento Nacional da Produção Mineral, 1973). [Levantamento de Recursos Naturais, 2.]

PROJETO RADAMBRASIL. Folha SB/SC. 18 Javari / Contamana: geologia, geomorfologia, pedologia, vegetação e uso potencial da terra (Rio de Janeiro: Departamento Nacional da Produção Mineral, 1967), 420 p. [Levantamento de Recursos Naturais, 13.]

Folha SC. 19 Rio Branco: geologia, geomorfologia, pedologia, vegetação e uso potencial da terra (Rio de Janeiro: Departamento Nacional da Produção Mineral, 1976), 464 p. [Levantamento de Recursos Naturais, 12.]

Folha SC. 20 Porto Velho: geologia, geomorfologia, pedologia, vegetação e uso potencial da terra (Rio de Janeiro: Departamento Nacional da Produção Mineral, 1978), 668 p. [Levantamento de Recursos Naturais, 16.]

Parte das folhas SC. 23 Rio São Francisco e SC. 24 Aracaju: geologia, geomorfologia, solos, vegetação e uso potencial da terra (Rio de Janeiro: Departamento Nacional da Produção Mineral, 1973). [Levantamento de Recursos Naturais, l.]

BRAZIL, Isaías Ramos. "O Potencial Petrolífero e as Perspectivas Exploratórias da Bacia do Solimões, Norte do Brasil", B. Geoci. Petrobrás, vol. 4, n 1, pp. 85-93 (Rio de Janeiro: janeiro/março 1990).

BRITO, Octávio Elísio Alves de. "O Ônus de uma Riqueza Mal Explorada”, Rev. Bras. Tecnol., vol. 13, n 2, pp. 3-12, (Brasília: abril/maio 1982).

CLOULD, P. "Entropy, Materials, and Posterity", Geologische Rundschau, vol. 66, n 3 , pp. 678-96 (junho 1977).

CONGRESSO BRASILEIRO DE GEOLOGIA, 35. Provincia Mineral de Carajás: litoestratigrafia e principais depósitos minerais (Belém: CVRD, SBG, 1988), 165 p.

CORDEIRO, Armando A. Campos. "Geologia Preliminar da Região de Andorinhas" em Simpósio de Geologia da Amazônia, vol. 1, pp. 45-9 (Belém: Sociedade Brasileira de Geologia, 1982).

; Alves, Carlos Alberto e Fonseca, Lucival Rodrigues da. "Geologia da Região da Serra dos Gradaús” em Simpósio de Geologia da Amazônia, vol. 1, pp. 50-3 (Belém: Sociedade Brasileira de Geologia, 1982).

"Pesquisa Geológica da Jazida de Wolframita da Pedra Preta, Rio Maria, PA” em Symposium Amazônico, 2, pp. 375-9 (Manaus: CNPq/DNPM, 1984).

COSTA, M. L. da, SÁ, J. H. da S. "Os Fosfatos Lateríticos da Amazônia Oriental: Geologia, Mineralogia, Geoquímica e Correlação com as Bauxitas da Amazônia” em Congresso Brasileiro de Geologia, 31, vol. 3, pp. 1459-72 (Camboriú: Sociedade Brasileira de Geologia, 1980).

DAYTON, Stan. "Brazil '75: For Mining, the Best Is Yet to Come", Engineering and Mining Journal, vol. 176, $\mathrm{n}^{\circ} 11$ (Nova York: novembro 1975), 286 p. [Número especial.]

ERICKSON, Ralph D. "Crustal Abundance of Elements and Mineral Reserves and Resources" em Brobst, Donald A. e Pratt, Walden P. (eds.) United States mineral resources (Washington: U.S. Government Printting Office, 1973), pp. 21-5. [U.S. Geological Survey. Professional Paper, 820.]

FARIAS, N. F. e Saueressig, R. "Jazida de Cobre Salobo $3^{\mathrm{A}}$ ' em Simpósio de Geologia da Amazônia, anexo dos anais, pp. 61-73 (Belém: Sociedade Brasileira de Geologia, 1982). 
FERREIRA, Manoel Rodrigues. As bandeiras de Paranpava (São Paulo: Prefeitura Municipal, 1977), $217 \mathrm{p}$. Expedição aos Martírios (São Paulo: Prefeitura Municipal, 1973), 29 p.

O mistério do ouro dos Martírios: desvendado o grande segredo das bandeiras paulistas (São Paulo: Gráfica Biblos, 1960), 457 p.

FLAWN, Peter T. Mineral resources: geology, engineering, economics, politics, law (Nova York: John Wiley e Sons, 1966), 406 p.

FONSECA, Francisco F. de Assis. "A Ocupação da Amazônia”, B. Inf. do Centro de Estudos de Engenharia de Minas Gerais, vol. 1, $\mathrm{n}^{\circ} \mathrm{l}$ (abril 1979). 1977), $112 \mathrm{p}$

As reservas minerais e o futuro da humanidade (Belo Horizonte: Vega, "Projeto Carajás", Ci. Terra, n ${ }^{\circ}$ 1, pp. 25-31 (Salvador: novembro/dezembro 1981).

FONSECA, Lucival Rodrigues da; RIGON, João Carlos e GONÇALEZ, Reinaldo. "Descoberta de Cobre na Formação Rio Fresco, Igarapé Bahia, Serra dos Carajás, PA" em Symposium Amazonico, 2, pp. 355-7 (Manaus: CNPq/DNPM, 1984).

FRANCO, José Roberto de Magalhães. As provincias estaniferas do Brasil (Manaus: DNPM, 1979), 28 p. [Trabalho apresentado durante o II Encontro Nacional sobre Estanho, Manaus, 1979.]

FREITAS, Maria de Lourdes Davies de. "Metodologia de Avaliação Ambiental Aplicada para um Caso de Enfoque Preventivo Projeto Ferro Carajás", Esp. Amb. Planej., vol. $1, \mathrm{n}^{\circ} \mathrm{l}$ (Rio de Janeiro: janeiro 1986).

FROST, John E. The successful exploration: a entrepreneurial approach (Washington: American Mining Congress, 1979), 20 p. [Apresentado no American Mining Congress, Mining Convention, Los Angeles, Califórnia, 1979.]

GAMA E SILVA, Roberto. Olho grande na Amazônia brasileira (Rio de Janeiro: Rio Fundo Ed., 1991), 143 p. [Ilustrado.]

. São mesmo nossos os minerais não energéticos?, coleção Visões e Revisões, 3 (Rio de Janeiro: Philobilion, 1985), 164 p. [Ilustrado.]

GARRIDO FILHA, Irene; Costa, Írio Barbosa da e Ribeiro, Glória Vanicore. "Estudo da Área Mineradora de Carajás", R. Bras. Geog., vol. 50, no 4, pp. 105-163 (Rio de Janeiro: outubro/dezembro 1988).

GIRAUD, Pierre-Noel. Geopolitique des ressources minières (Paris: Economica, 1983), $750 \mathrm{p}$.

GROSSLING, Bernardo F. "Future Mineral Supply", Econ. Geol., vol. 65, n 3, pp. 348-9 (maio 1970).

HALL, D. O. e ROSILlO-CALlE, F. "A Reciclagem do $\mathrm{CO}_{2}$ por Biomassa: Bioprodutividade Global e Problemas de Desmatamento", Esp. Amb. Planej., vol. 2, $\mathrm{n}^{\mathrm{O}} 12$ (Rio de Janeiro: setembro 1990).

HERFINDAHL, Orris Clement e Brooks, David B. Resource economics: selected works of Orris C. Herfindabl (Washington: Resources for the Future; Baltimore: Johns Hopkins University Press, 1974), 316 p.

HIRATA, Walter Kou; RIGON, João Carlos; KADEKARU, Kiyoshi et alii. “Geologia 
Regional da Província Mineral de Carajás" em Simpósio de Geologia da Amazônia, vol. 1, pp. 100-9 (Belém: Sociedade Brasileira de Geologia, 1982).

HOLMES, Stanley W. Exploration philosophy is the Key: some find mines and some do not: why?, tradução de F. G. Chaves (s. l.: s. ed., 1977), 27 p.

HUBBERT, M. K. "Role of Geology in Transition to a Mature Industrial Society", Geologische Rundschau, vol. 66, nº 3, pp. 354-78 (junho 1977).

JOÃO, Xafi da Silva Jorge; Neves, Agildo Pina e Leal, José Waterloo Lopes. "Ouro de Serra Pelada: Aspectos da Geologia e Garimpagem" em Simpósio de Geologia da Amazônia, vol. 2, pp. 52-61 (Belém: Sociedade Brasileira de Geologia, 1982).

KOTSCHO, Ricardo. Serra Pelada: uma ferida aberta na selva (São Paulo: Brasiliense, 1984). 106 p. [Ilustrado].

LOBATO, Fabiano Sayão. Middle/lower Amazon Project(s.l.: Kingwood, 1990), 31 p. [21 figuras].

"Tesouro na Amazônia", O Globo, caderno 2, p. 32 (Rio de Janeiro, 7 de novembro de 1991).

MACHADO, Iran F. Recursos minerais; politica e sociedade (São Paulo: Edgard Blücher, Pró-Minério, 1989). 410 p.

MARANHÃO, Ricardo. "Uma Saída para o Terceiro Mundo", Ci. Terra, no 5, pp. 408 (Salvador: julho/agosto 1998).

MASCARENHAS, Raymundo Pereira. "Planificação e Gestão de Recursos Minerais", Brasil Min., vol. 5, no 43, pp. 46-56, (São Paulo: junho 1987).

MEIRELES, E. de M.; Teixeira, José Thadeu; Lourenço, Rubens Seixas et alii. "Geologia, Estrutura e Mineralização Aurífera de Serra Pelada" em Congresso Brasileiro de Geologia, 32, vol. 3, pp. 900-11 (Salvador: Sociedade Brasileira de Geologia, 1982).

MELLO, Thiago de. Amazônia, a menina dos olhos do mundo (Rio de Janeiro: Civilização Brasileira, 1991), 212 p. [Ilustrado.]

MEYER, D. J. K. e GONÇALEZ, R. "A Descoberta da Jazida de Cobre Salobo 3A através da Geoquímica" em Congresso Brasileiro de Geologia, 32, vol. 5, pp. 1795-800 (Salvador: Sociedade Brasileira de Geologia, 1982).

NEVES, Carlos Alberto de Oliveira. "Prospectos Potenciais e Áreas Prioritárias para Exploração na Bacia do Amazonas”, B. Geoci. Petrobrás, vol. 4, no 1, pp. 95-103 (Rio de Janeiro: janeiro/março 1990).

OLIVEIRA, Avelino Ignácio de. "Reconhecimento Geológico no Rio Xingu, Estado do Pará", B. Serv. Geol. Mineral. no 29 (Rio de Janeiro: 1928).

PARK JR., Charles F. e Freeman, Margaret C. Affluence in jeopardy: minerals and the political economy (São Francisco: Freeman, Cooper and Company, 1968), 368 p.

PETERS, T. et alii. “The Manganese Deposits of Buritirama, Pará, Brazil” Scheweiz, Mineral Petrogr. Mitt., vol. 57, n 3, pp. 313-27 (Zurique: 1977).

PETRI, Setembrino e Fúlfaro, Vicente José. Geologia do Brasil: Fanerozóico (São Paulo: T.A. Queiroz, Ed. da Universidade de São Paulo, 1983), 631 p. [Biblioteca de Ciências Naturais, 9.]

PINTO, Lúcio Flávio. “A Crise Atinge a Amazônia”, Ci. Hoje, vol. 2, no 10, pp. 74-5 (Rio de Janeiro: janeiro/fevereiro 1984). 
PINTO, Lúcio Flávio.“A Dimensão Social Omitida”, Ci. Hoje, vol. 1, nº 3, p. 46 (Rio de Janeiro: novembro/dezembro 1982).

Amazônia: no rastro do saque (São Paulo: Hucitec, 1980), 219 p. [Ciências Sociais. Série Realidade Social.] . Amazônia: o anteato da destruição (Belém: Grafisa, 1977), 372 p. Carajás: o ataque ao coração da Amazônia (Rio de Janeiro: Ed. Marco Zero, 1982), 112 p. [Coleção Nossos Dias, 2.]

PROJETO DE DESENVOLVIMENTO Integrado da Bacia do Araguaia-Tocantins (PRODIAT). Diagnóstico da Bacia do Araguaia-Tocantins (Brasília: 1982). [4 volumes ilustrados.]

RIBEIRO, Berta G. Amazônia urgente: 5 séculos de história e ecologia (Belo Horizonte: Itatiaia, CNPq, INEP, 1990), 272 p. [Ilustrado.]

RIDLEY, R. S. e Kaba, A. F. "Brazil Battles the Jungle to Mine CARAJÁS' Minerals”, Word Mining, vol. 36, n ${ }^{\circ}$ 1, pp. 50-7 (São Francisco: janeiro 1983).

RIVA JR., Joseph P. Brazilian petroleum status (Washington: The Library of Congress, Congressional Research Service, 1989), 21 p. [CRS Report for Congress.]

ROCHA, Gerôncio Albuquerque (coord.) Em busca do ouro; garimpos e garimpeiros do Brasil (São Paulo: CONAGE; Rio de Janeiro: Ed. Marco Zero, 1984), 222 p. [Ilustrado; coleção Nossos Dias.]

SÁ, Paulo Cesar R. O. "Bauxita: Produtores de Alumínio Buscam Redução no Preço", Brasil Min., vol. 3, nº 27, pp. 32-4 (São Paulo: fevereiro 1986).

"Carajás e a Dívida Externa”, Rev. Bra. Tecnol., vol. 13, n 4, pp. 11-22 (Brasília: agosto/setembro 1982).

"Carajás Face à Crise, e a Crise Face a Carajás" Rev. Bra. Tecnol., vol. 15, $n^{\circ} 2$, pp. 12-23 (Brasília: março/abril 1982).

"Carajás: o Mito Desfeito", Ci. Hoje, vol. 2, no 10, pp. 76-80 (Rio de Janeiro: janeiro/fevereiro 1984).

"Os Concorrentes de Carajás", Brasil Min., vol. 2, n 16, pp. 14-8 (São Paulo: março 1985).

e Marques, Isabel. "A Reestruturação da Indústria Internacional de Alumínio”, Brasil Min., vol. 4, n 36, pp. 44-9 (São Paulo: outubro 1986).

. "O Projeto Alumar e a Questão Energética”, Brasil Min., vol. 4, n 31, pp. 22-7 (São Paulo: junho 1986).

"Projeto Albrás/Alunorte: do Sonho ao Pesadelo", Brasil Min., vol. 5, n] 38, pp. 44-8 (São Paulo: janeiro 1987).

SALOMÃO, Elmer Prata. "A Força do Garimpo", Rev. Bras. Tecnol., vol. 13, n 2, pp. 13-20 (Brasília: abril/maio 1982).

SANTOS, Breno A. dos. Amazônia: potencial mineral e perspectivas de desenvolvimento (São Paulo: T. A. Queiroz, Ed. da Universidade de São Paulo, 1981), 256 p. [Ilustrado; Biblioteca de Ciências Naturais, 7.]

. "Carajás: a Realidade do Potencial Mineral”, Ci. Hoje, vol. 1, n 3, pp. 37 40 (Rio de Janeiro: novembro/dezembro 1982). 
SANTOS, Breno A. dos. "Carajás e o Desenvolvimento Regional", Rev. Bras. Tecnol., vol. 13, $\mathrm{n}^{\circ} 5$, pp. 9-18 (Brasília: outubro/novembro 1982).

“Carajás, História e Perspectivas', Esp. Amb. Planej., vol. 1, nº 2, pp. 13-

38 (Rio de Janeiro: fevereiro 1986).

"Conhecimento e Uso dos Recursos Minerais da Amazônia”, Esp. Amb.

Planej., vol. 1, n 2 , pp. 3-12, (Rio de Janeiro: fevereiro 1986).

SANTOS, Roberto Araújo de Oliveira. História econômica da Amazônia: 1800-1920

(São Paulo: T. A. Queiroz, 1980), 358 p. [Biblioteca Básica de Ciências Sociais; série 1: Estudos Brasileiros, 3.]

SEMINÁRIO SOBRE DESENVOLVIMENTO Econômico e Impacto Ambiental em Áreas do Trópico Úmido Brasileiro, Belém, 1986. A experiência da CVRD (Rio de Janeiro: CVRD, 1987), 334 p. [Ilustrado].

SIOLI, Harald. Amazônia: fundamentos da ecologia da maior região de florestas tropicais (Petrópolis: Vozes, 1985). 72 p. [Ilustrado.]

SMITH, Vernon L. (ed.) Economics of natural \& environmental resources (Nova York: Gordon and Breach, 1977). 502 p.

SOUZA, Laura de Mello e. Desclassificados do ouro: a pobreza mineira no século XVIII (Rio de Janeiro: Graal, 1982), 237 p. [Biblioteca de História, 8.]

STERNBERG, Hilgard O'Reilly. "Desenvolvimento e Conservação", Esp. Amb. Planej., vol. 1, $\mathrm{n}^{\circ} 5$ (Rio de Janeiro: maio 1986).

TEIXEIRA, J. T. e Hirata, W. K. Depósitos de cassiterita do granito Antonio Vicente (Belém: DOCEGEO, 1980), 11 p. [Trabalho apresentado no Congresso Brasileiro de Geologia, 31, Camboriú, SC.]

TOLBERT, Gene E.; Santos, Breno A. dos; Almeida, Erasto B. de et alii. "Recente Descoberta de Ocorrência de Minério de Ferro no Estado do Pará, Brasil", Miner. Metal., vol. 48, $\mathrm{n}^{\mathrm{O}} 288$, pp. 253-6 (Rio de Janeiro: dezembro 1968).

VALE, Armínio Gonçalves; João, Xafi da Silva Jorge; Leal, José Waterloo Lopes et alii. "Ouro dos Gradaús: Geologia e Garimpagem" em Simpósio de Geologia da Amazônia, vol. 2, pp. 116-35 (Belém: Sociedade Brasileira de Geologia, 1982).

VALVERDE, Orlando. "Ecologia e Desenvolvimento da Amazônia”, Rev. Bras. Tecnol., vol. 12, n 4, pp. 3-16 (Brasília outubro/dezembro 1981).

. Grande Carajás: planejamento da destruição (Rio de Janeiro: Forense Universitária, Universidade de São Paulo, Universidade de Brasília, 1989), 170 p. [Ilustrado.]

VOGELY, William A. e Risser, Hubert E. (eds.) Economics of the mineral industries; a series of articles by specialists (Nova York: American Institute of Mining, Metallurgical, and Petroleum Engineers, 1976), 863 p.

WARD, Barbosa e Dubos, Renê. Uma terra somente : a preservação de um pequeno planeta (São Paulo: Edgar Blucher, Melhoramentos, Ed. da Universidade de São Paulo, 1973), $277 \mathrm{p}$.

WARREN, Kenneth. Mineral resources (Devon: David \& Charles, Newton Abbot, 1973), 272 p. [Ilustrado.]

ZENKER, A. O. "Ambientes Geológicos Favoráveis para Urânio na Amazônia” em 
Congresso Brasileiro de Geologia, 32, vol. 5, pp. 2086-98 (Salvador: Sociedade Brasileira de Geologia, 1982).

Breno Augusto dos Santos é geólogo, ex-secretário de Minas e Metalurgia do Ministério de Minas e Energia, ex-presidente da Rio Doce Geologia e Mineração (DOCEGEO CVRD) e autor do livro Amazônia: potencial mineral e perspectivas de desenvolvimento (prêmio Jabuti da Câmara Brasileira do Livro, na categoria Ciências Naturais, em 1982).

Texto publicado originalmente em inglês em Amazonia - Heaven of a New World (Rio de Janeiro: Editora Campus, 1998), coordenado por Maria de Lourdes Davies de Freitas, a quem a revista agradece ter autorizado a publicação da versão em português. 